\title{
1 Demonstrating multiple benefits from periodically harvested fisheries closures
}

2 Author affiliation: Jordan S. Goetze ${ }^{1,3}$ (gertza@gmail.com), Joachim Claudet ${ }^{4,5}$

3 (joachim.claudet@gmail.com), Fraser Januchowski-Hartley ${ }^{6,7}$ (f.a.hartley@gmail.com), Tim J.

$4 \quad$ Langlois $^{1,2}$ (timothy.langlois@uwa.edu.au), Shaun K. Wilson ${ }^{1,8}$

5 (Shaun.Wilson@dpaw.wa.gov.au), Crow White9 (cwhite31@calpoly.edu), Rebecca Weeks ${ }^{10}$

6 (rebecca.weeks@jcu.edu.au), Stacy D. Jupiter ${ }^{11}$ (sjupiter@wcs.org)

$7{ }^{1}$ The UWA Oceans Institute, The University of Western Australia, 35 Stirling Highway, Crawley, W.A. 6009,

8 Australia

$9{ }^{2}$ School of Biological Sciences, The University of Western Australia, 35 Stirling Highway, Crawley, W.A. 6009, 10 Australia

$11{ }^{3}$ Department of Environment and Agriculture, Curtin University, Bentley Campus, W.A. 6485, Australia

$12{ }^{4}$ National Center for Scientific Research, CRIOBE, USR 3278 CNRS-EPHE-UPVD, 66860 Perpignan, France

$13 \quad{ }^{5}$ Laboratoire d'Excellence CORAIL, France

$14{ }^{6}$ Department of Geography, College of Life and Environmental Sciences, University of Exeter, UK

$15 \quad{ }^{7}$ UMR 248 MARBEC/UMR250 ENTROPIE, UM2-CNRS-IRD-IFREMER-UM1, Université Montpellier

$16{ }^{8}$ Marine Science Program, Department of Parks and Wildlife, Kensington, Western Australia, Australia, 6151

$17{ }^{9}$ Department of Biological Sciences, California Polytechnic State University, San Luis Obispo, California 93407

18 USA

$19{ }^{10}$ Australian Research Council Centre of Excellence for Coral Reef Studies, James Cook University, Townsville, 20 QLD 4811, Australia 
$21{ }^{11}$ Wildlife Conservation Society, Melanesia Program, Suva, Fiji

22 Corresponding author: Jordan S. Goetze (gertza@gmail.com)

\section{Abstract}

24 1. Periodically harvested closures (PHCs) are one of the most common forms of fisheries management in Melanesia, demonstrating multiple objectives, including sustaining fish stocks and increasing catch efficiency to support small-scale fisheries. No studies have comprehensively assessed their ability to provide short-term fisheries benefits across the entire harvest regime.

2. We present a novel analytical framework to guide a meta-analysis and assist future research in conceptualizing and assessing the potential of PHCs to deliver benefits for multiple fisheries-related objectives.

3. Ten PHCs met our selection criteria and on average, they provided a $48 \%$ greater abundance and $92 \%$ greater biomass of targeted fishes compared with areas open to fishing prior to being harvested.

4. This translated into tangible harvest benefits, with fishers removing $21 \%$ of the abundance and $49 \%$ of the biomass within PHCs, resulting in few post-harvest protection benefits.

5. When PHCs are larger, closed for longer periods or well enforced, short-term fisheries benefits are improved. However, an increased availability of fish within PHCs leads to greater removal during harvests. 
41 Synthesis and applications: Periodically harvested closures (PHCs) can provide short-term

42 fisheries benefits and use of the analytical framework presented here, will assist in determining 43 long term fisheries and conservation benefits. We recommend, PHCs be closed to fishing for as 44 long as possible, be as large as possible, compliance encouraged via community engagement and 45 enforcement and strict deadlines/goals for harvesting set to prevent overfishing.

46 Keywords: fisheries management, conservation, customary management, meta-analysis, marine 47 reserve, small scale fisheries, analytical framework, locally managed marine areas, periodically 48 harvested closures Introduction

50 Inshore fisheries resources that support small-scale coral reef fisheries are in decline (Newton et 51 al. 2007; Mora et al. 2009), impacting on food security and livelihood for millions of coastal 52 residents (Pauly, Watson \& Alder 2005; Bell et al. 2009). Various spatial (e.g., no-take marine 53 reserves, NTMRs) and non-spatial (e.g., quotas, gear restrictions) management strategies are 54 being implemented to achieve fisheries management, conservation and socio-cultural objectives 55 with mixed success (Gaines et al. 2010; Rassweiler, Costello \& Siegel 2012). In small-scale 56 fisheries, these objectives often include maintaining or improving: long-term sustainable yield 57 and profit; catch efficiency; reproductive capacity of fisheries; biodiversity and ecosystem 58 function (Jupiter et al. 2014). Because achievement of these objectives requires optimizing 59 different factors, trade-offs may arise in order to achieve multiple objectives simultaneously 60 (Cohen \& Steenbergen 2015; Daw et al. 2015). 
61 Periodically harvested closures (PHCs) are functionally similar to rotational harvests of fishing 62 grounds (e.g. scallop fisheries; Hart 2003; Valderrama \& Anderson 2007) and have opening 63 regimes that can range from mostly closed to mostly open (Cohen \& Foale 2013). PHCs are 64 commonly applied in Indo-Pacific coral reef fisheries as a strategy to increase catch efficiency 65 and provide for socioeconomic and cultural needs (Jupiter et al. 2012, 2014; Cohen \& Foale 66 2013). The number of PHCs implemented is increasing rapidly with a current estimate of $>1000$ 67 established across Melanesia (H. Govan, pers. comm.). This rapid increase in PHCs is partially 68 attributed to poor compliance with NTMRs and conventional fisheries management resulting in 69 an increased interest in repurposing customary practice (Johannes 2002; Foale \& Manele 2004; 70 Cohen \& Foale 2013). The increased reliance on PHCs to manage local fish stocks highlights the 71 importance in understanding the dynamics of this strategy.

72 Historically, PHCs were implemented to increase catch efficiency through a decrease in fish 73 wariness, as fishers observed that the behaviour of fish changes during closure, making them 74 easier to catch (Cinner et al. 2006; Feary et al. 2011). More recently an increase in catch 75 efficiency within PHCs has been observed for invertebrates harvested via gleaning (collection 76 during low tide) (Cohen \& Alexander 2013) and fish through a reduction in wariness to 77 spearfishers (Januchowski-Hartley, Cinner \& Graham 2014; Goetze et al. 2017). However, the 78 increased catchability also means that a small amount of fishing effort can effectively remove 79 substantial biomass (Jupiter et al. 2012). Consequently, pulse harvests in PHCs benefit fishers in 80 the short-term, but potentially increase the likelihood of overharvesting, compromising long-term 81 conservation and fisheries management objectives (Jupiter et al. 2012; Cohen \& Foale 2013). 
82 Despite a growing literature on PHCs (Cinner et al. 2006; Bartlett et al. 2009; Jupiter et al. 2012;

83 Cohen \& Alexander 2013; Cohen, Cinner \& Foale 2013; Januchowski-Hartley, Cinner \&

84 Graham 2014; Goetze et al. 2015), there has been little quantitative work to understand their

85 ability to achieve these short- and long-term fisheries and conservation objectives.

86 The complex nature of PHCs with highly variable harvesting regimes (Cohen \& Foale 2013) and

87 their use to achieve multiple objectives simultaneously (Jupiter et al. 2014) has made it difficult

88 to generalize about their effectiveness. By contrast, drivers of NTMRs performance have been

89 investigated extensively using meta-analytical approaches (e.g., Côté, Mosqueira \& Reynolds

90 2001; Halpern 2003; Claudet et al. 2008, 2010; McClanahan et al. 2009; Lester et al. 2009;

91 Molloy, McLean \& Côté 2009; Vandeperre et al. 2011). Quantitative analyses of individual

92 PHCs indicate variability in effectiveness (Cinner et al. 2006; Bartlett et al. 2009; Jupiter \& Egli

93 2011) and suggest pulse harvests may be sustainable where total effort and catch from PHCs are

94 low when compared with continuously fished reefs (Cohen, Cinner \& Foale 2013). Meanwhile,

95 theoretical analysis indicates that, under certain harvest regimes, PHCs can generate fisheries

96 yields and in situ biomass levels matching those achievable under optimal non-spatial

97 management or with NTMRs (Carvalho et al. 2015). Importantly, these yields may be achieved

98 with greater catch efficiency under a PHC strategy (Januchowski-Hartley, Cinner \& Graham 99 2014).

100 To assess empirically whether PHC practice matches theory, we developed a framework to assist

101 future research in both conceptualizing and assessing the potential multiple benefits of PHCs for 102 fisheries and conservation management. The aim of this framework is to deconstruct the variety 
103 of potential effects of periodically harvested closures (more numerous and complex than NTMRs

104 due to harvesting regimes) and present the associated experimental design and effect sizes that

105 are needed to quantitatively assess their magnitude. We then reviewed the literature and available

106 unpublished data to gather a comprehensive database to quantitatively assess the ability of PHCs

107 to provide short-term fisheries benefits to local communities. We hypothesized that PHCs would

108 provide pre-harvest protection benefits as evidenced by a greater abundance and biomass of

109 targeted fishes within their boundaries, but that these benefits would not be observed post-

110 harvest due to removal during harvests. Finally, we assessed which factors contribute to short-

111 term fisheries and harvest benefits and predicted that PHCs which are larger, closed for longer

112 periods or well enforced would provide increased benefits.

\section{Materials and Methods}

114 Analytical framework

115 We developed hypotheses, effect sizes and sampling designs to assess eight potential social-

116 ecological benefits (indicated with italicized text) derived from PHCs (Table 1). We use the

117 terminology "PHC" to refer to areas within a periodically harvested closure and "Open" for areas

118 outside of the PHC, in which fishing is always allowed. Pre-harvest protection benefits result

119 from increased availability of abundance or biomass within a PHC compared with areas open to

120 fishing prior to a harvest event. PHCs may have experienced historical harvest events depending

121 on the timing of initial surveys making this effect size distinct when compared to assessing the

122 benefits of a NTMR. The pre-harvest protection benefit is comparable to a measurement of post-

123 harvest recovery, which is the same effect size measure taken at some defined time following a 
124 harvest event. Post-harvest protection benefits are shown by an increased level of abundance or 125 biomass remaining after the harvest, while maintenance of post-harvest protection indicates that 126 these benefits are retained through a subsequent harvest. Harvest benefits to fishing communities 127 occur when a large proportion of the abundance and biomass is efficiently removed from a PHC 128 during a pulse fishing event. Recovery of pre-harvest protection assesses the relative state of the 129 fishery to the levels of abundance or biomass prior to the last harvest. The conservation benefit 130 evaluates the ability of a PHC to increase fish stocks compared to NTMRs. Finally, the 131 sustainability of periodic harvest practice assesses the ability of PHCs to maintain all of these 132 benefits over the long term.

\section{Literature search}

134 We performed a literature search of published information to assess the eight benefits in Table 1.

135 Single and combined terms were used to search all databases of the ISI Web of Knowledge and 136 Google Scholar for literature on PHCs (see search terms in Table S1). A total of 85 publications 137 had information on an area that had been harvested after being closed to fishing. The reference 138 lists of these publications were examined to identify additional studies (mostly grey literature) 139 that were not found in the initial literature search. This identified an additional 40 studies, giving 140 a total of 125 publications with information on PHCs. Of these, 29 studies reported empirical 141 data that could be extracted from tables and/or figures. Additional unpublished data from 5 PHCs 142 was provided by authors, J. Goetze and S. Jupiter.

\section{Selection criteria and data evaluation}


144 Selection criteria were established to ensure that the data could be used to quantify at least one of 145 the potential benefits of PHCs (Table 1): (i) studies must have collected abundance and/or 146 biomass data inside and outside of a PHC; (ii) PHCs needed to be strictly no-take when closed to 147 fishing; (iii) control sites must have been located in areas that were continuously fished; (iv) data 148 collection methods had to be standardized inside and outside of the PHC, before and after the 149 harvest and fisheries independent; and (v) adequate statistical information had to be provided, 150 including number of replicates (transects), means, and error estimates. A total of 11 studies 151 (including the 5 unpublished datasets) met these criteria. All but one presented information on 152 coral reef fishes, thus we restricted analyses to coral reef fish in 10 PHCs (Table 2). Insufficient 153 replication within existing empirical datasets constrained our ability to assess the ability of PHCs 154 to deliver protection benefits, allowing us to address only 3 of 8 questions posed in our analytical 155 framework (Table 1): thus we only assessed the effectiveness of PHCs to deliver pre-harvest 156 protection, harvest and post-harvest protection benefits. We were unable to assess how long the 157 PHC will take to recover to pre-harvest levels, provide benefits after a certain period of recovery, 158 maintain post-harvest protection benefits and conserve abundance/biomass relative to no-take 159 marine reserves; however, our analytical framework outlines methods for conducting these 160 assessments once the data become available. In addition, paired series were not available for 161 benefits 1 to 3 , preventing us from assessing the sustainability of these benefits.

162 The data presented in these ten studies were used following two steps: (i) if there were multiple 163 harvest sampling records, surveys for before/after values were chosen closest to the harvest dates 164 to ensure they provided the most accurate information on PHC protection and harvest impacts; 
165 (ii) observations must have been independent (i.e., when multiple harvests were sampled, we 166 used data before and after the initial harvest and when multiple studies occurred in the same 167 PHC, we chose that which had the most comprehensive data).

168 A conceptual diagram was created to illustrate the theoretical functioning of a PHC and areas 169 open to fishing and the calculation of effect sizes used to assess pre-harvest protection, post170 harvest protection and harvest benefits (Fig. 1). In order to simplify the diagram we assume there 171 is no change in abundance/biomass in open areas, full compliance with the fishing restriction 172 inside the PHC and that abundance and biomass increase during closure periods. During harvest 173 events we also assumed fishing effort is initially intense and decreases towards the end of the 174 harvest, as has been documented empirically (Cohen, Cinner \& Foale 2013). Multiple harvests of 175 the same level are shown to indicate a system that is in equilibrium, i.e., the overall 176 biomass/abundance in the system is not increasing or decreasing.

\section{Sampling design and methods (unpublished data)}

178 Surveys were carried out on reefs adjacent to five villages on Koro (Nakodu, Tuatua), Ovalau 179 (Nauouo, Natokalau) and Vanua Levu (Kiobo) islands in Fiji in 2013 and 2014. PHCs had been 180 established for 3-8 years prior to surveys, though the frequency at which they had been 181 previously harvested and level of compliance with management varied (Table 2). Surveys were 182 carried out 1-2 days before and 1-2 days after harvests, which lasted between 1 to 7 days and 183 involved line fishing, spear fishing and/or fish drives into gill nets (Table S3). We sampled 184 between 2 and 5 sites inside each of the five PHCs (depending on PHC size), and 4 to 6 sites in 185 open areas (depending on comparable available habitat, Table S2). At each site, the fish 
community was sampled by conducting stereo diver operated video (stereo-DOV) surveys along

187 six replicate $5 \times 50 \mathrm{~m}$ transects separated by $10 \mathrm{~m}$, following (Goetze et al. 2015). This matched

188 the transect length used to estimate abundance and biomass from all studies extracted from the

189 PHC literature (Table S2). Stereo-DOVs are one of the most effective methods for detecting

190 harvest impacts on targeted species within PHCs (Goetze et al. 2015) and have been shown to be

191 broadly comparable to underwater visual census (Holmes et al. 2013). Stereo-DOVs were used

192 to collect abundance and biomass calculated using the standard length-weight equations and

193 values from FishBase (Froese \& Pauly 2015), preferentially selected from sites closest to Fiji

194 (Jupiter \& Egli 2011). System design and procedures for video analysis followed Goetze et al. 195 (2015).

Factors influencing protection benefits

197 Previous meta-analyses of NTMRs showed that protection effectiveness is a function of 198 enforcement (Guidetti et al. 2008), fishing pressure outside of the reserve (Côté, Mosqueira \& 199 Reynolds 2001) and the size and age of reserves (Claudet et al. 2008). PHCs, however, have 200 complex regimes of opening and closing to fishing and their popularity in small scale fisheries is 201 partially attributed to poor compliance with NTMRs (Foale \& Manele 2004; Jupiter et al. 2012; 202 Cohen \& Foale 2013). Here we assessed how PHC benefits were affected by: (i) compliance 203 with PHC no-take rule (Compliance); (ii) fishing pressure outside of the PHC when closed 204 (Fishing Pressure Outside); (iii) fishing effort within the PHC when harvested (PHC Harvest 205 Effort); (iv) size of PHC in $\mathrm{km}^{2}$ (Size); (v) number of years since the PHC was established when 206 before-harvest sampling took place (Years Established); or (vi) number of years the PHC was 
207 closed to fishing (following prior harvest or since establishment) when before-harvest sampling 208 took place (Time Closed)(Table 2). For published data, information on Size, Time Closed and 209 Years Established was extracted from each manuscript (Table 2). As the same quantitative data 210 collected in this study were not always available in the literature, assessments of Harvest Effort, 211 Fishing Pressure Outside and Compliance were converted to categorical two-point scales (High 212 or Low). This was achieved by ranking all PHCs with matching data and then assessing where 213 the remaining PHCs fit on this scale, using information reported in each manuscript and expert 214 knowledge (Table S3) Categorisation occurred at a workshop with all authors present and at least 215 one author had either been directly involved with each study or worked in the same location as 216 the PHC.

217 To estimate fishing pressure during harvest events for the unpublished data (Harvest Effort), we 218 recorded catch per unit effort (CPUE), fishing methods, and harvest duration for each PHC 219 (Table 2, S3). Estimates of Compliance were based on surveys with village spokespersons, 220 fishers and other key informants, who were asked to rate compliance as low (frequent breaches 221 of management rules) or high (occasional or infrequent offenses of management rules), based on 222 their direct observations within each village. The extent of fishing in areas outside of PHCs was 223 also collected from key informant surveys, who estimated the number of locally-operated boats 224 within a village; the number of boats from outside the village observed in the fishing area each 225 week and the number of licensed fishers (Table S3). Where available, catch per unit effort data 226 was also reported. 
227 For unpublished data, species were classified as target or non-target based on whether they were 228 caught during the harvest, so that classifications were specific to each PHC (see Table S4 for a 229 full list of targeted/non-targeted species). For published studies targeted/non-targeted species 230 were designated by the authors (see Table S2 for a summary). Variation in the occurrence and 231 target status of species across countries resulted in different groupings of species across studies, 232 limiting analysis to targeted and non-targeted groupings. In all studies, species were combined 233 by summing the targeted and non-targeted abundance/biomass at the transect level.

\section{Statistical analyses}

235 Three effect sizes were developed in order to assess PHC benefits 1 to 3 in the analytical 236 framework (Table 1). Log-ratio effect sizes and confidence intervals were used to quantify 237 proportionate change across all metrics, and account for variation in the sampling methods, focal 238 species and study locations (Hedges, Gurevitch \& Curtis 1999). For each PHC $i$, the ability to 239 deliver a pre-harvest protection benefit $\left(E_{b, i}\right)$, was calculated as the log-ratio of the mean 240 abundance or biomass in the PHC before $(P b), \bar{X}_{P b, i}$ and the Open before $(O b), \bar{X}_{O b, i}$, 241 respectively:

$$
E_{b, i}=\ln \left(\frac{\bar{X}_{P b, i}}{\bar{X}_{O b, i}}\right)
$$

242 Variance of the effect sizes were calculated as:

$$
v_{E_{b, i}}=\frac{\sigma_{P b, i}^{2}}{n_{P b, i} \times \bar{X}_{P b, i}^{2}}+\frac{\sigma_{O b, i}^{2}}{n_{O b, i} \times \bar{X}_{O b, i}^{2}}
$$


243 where $v_{E_{b, i}}$ is the variance associated with the effect size $E_{b, i}, \sigma_{P b, I}$ and $\sigma_{O b, i}$ are the standard 244 deviations associated with the means $\bar{X}_{P b, i}$ and $\bar{X}_{O b, i}$, respectively, and $n_{P b, i}$ and $n_{O b, i}$, are the 245 number of transects used to calculate each mean (Hedges, Gurevitch \& Curtis 1999).

246 For each PHC $i$, the ability to deliver a post-harvest protection benefit $\left(E_{a, i}\right)$, was calculated as 247 the log-ratio of the mean abundance or biomass per transect in the PHC after $(P a), \bar{X}_{P a, i}$ and the 248 Open after $(O a), \bar{X}_{O a, i}:$

$$
E_{a, i}=\ln \left(\frac{\bar{X}_{P a, i}}{\bar{X}_{O a, i}}\right)
$$

249 Variance of the effect sizes were calculated as:

$$
v_{E_{a, i}}=\frac{\sigma_{P a, i}^{2}}{n_{P a, i} \times \bar{X}_{P a, i}^{2}}+\frac{\sigma_{O a, i}^{2}}{n_{O a, i} \times \bar{X}_{O a, i}^{2}}
$$

250 where $v_{E_{a, i}}$ is the variance associated with the effect size $E_{a, i}, \sigma_{P a, I}$ and $\sigma_{O a, i}$ are the standard 251 deviations associated with the means $\bar{X}_{P a, i}$ and $\bar{X}_{O a, i}$, respectively, and $n_{P a, i}$ and $n_{O a, i}$, are the 252 number of transects used to calculate each mean.

253 For each PHC $i$, the harvest benefit $\left(E_{h, i}\right)$, was defined as the difference in the mean abundance or 254 biomass between the PHC after, $\bar{X}_{P a, i}$, and before $\bar{X}_{P b, i}$ the harvest, while controlling for 255 differences in Open areas after $\bar{X}_{O a, i}$ and before $\bar{X}_{O b, i}$ the harvest:

$$
E_{h, i}=\ln \frac{\left(\bar{X}_{P a, i} / \bar{X}_{P b, i}\right)}{\left(\bar{X}_{O a, i} / \bar{X}_{O b, i}\right)}
$$


256 Variance of the effect sizes were calculated as:

$$
v_{E_{h, i}}=\sum^{P a, P b, O a, O b} \sigma_{i}^{2} /\left(n_{i} \times \bar{X}_{i}^{2}\right)
$$

257 where $v_{E_{h, i}}$ is the variance associated with the effect size $E_{h, i}, \sigma_{i}$ is the standard deviations 258 associated with the mean $\bar{X}_{i}$, and $n_{i}$ is the number of transects summed for the PHC after $(P a)$, 259 PHC before $(\mathrm{Pb})$, Open after $(\mathrm{Oa})$ and Open before $(\mathrm{Ob})$.

260 We then used a mixed effects weighted meta-analysis where weights of each individual effect 261 size incorporate these variances as follows:

$$
w_{j, i}=\frac{1}{v_{E_{j, i}}+v_{j, a}}
$$

263 where $w_{j, i}$ is the weight associated to each effect $E_{j, i}, v_{E i, j}$ is the within study variance of each 264 PHC benefit $j$ (pre-harvest, post-harvest or harvest as defined above) and $v_{j, a}$ is the among-study 265 variance for each benefit $j$. In a meta-analysis framework, a mixed effect procedure is used when 266 studies are not expected to all share the same true effect (i.e. there is an among-study variation in 267 addition to sampling error; random effect) and where the effect of moderators (covariates) is 268 assessed (mixed-effect). The among study variance was obtained using the generalized equation 269 reported in (Hedges \& Pigott 2004). Confidence intervals for group and overall effect sizes were 270 derived from a Student's $t$ statistic. Given the possibility of type I error with multiple testing, we 271 recommend a cautious approach when interpreting our results and suggest to use the 95\% 
272 confidence intervals to assess confidence in the direction of the result rather than accepting or 273 rejecting each hypothesis.

274 We assessed the effects of moderators Compliance, Fishing Pressure Outside, PHC Harvest 275 Effort, Size, Time Closed and Years Established on each of the effect sizes described above using 276 comparisons among factors for categorical variables and linear models for quantitative variables.

277 Correlation between moderators were tested using, Pearson's correlations for comparisons 278 between continuous variables, Cramer's V for nominal variables and intra-class correlations 279 (ICC) for continuous vs. nominal moderators. Weak correlations were observed between all 280 moderators, except for PHC Harvest Effort and Time Closed which was moderate (Table S5). To 281 assess whether a set of effect sizes are heterogeneous (i.e. varied across PHCs), we calculated the 282 total heterogeneity $Q t$ and tested it against a $\chi^{2}$ distribution with $n-1$ degrees of freedom $(n$ 283 being the number of studies), as outlined in Hedges and Olkin (1985). We used the package 284 metafor with restricted maximum-likelihood estimator (Viechtbauer 2010) in R language for 285 statistical computing (R Core Team 2014).

\section{Results}

287 Pre-harvest protection benefits

288 On average PHCs provided pre-harvest protection benefits, with a $48 \%$ greater abundance and $28992 \%$ greater biomass of targeted fishes when compared to open areas; however, these results 290 were heterogeneous, suggesting variation across PHCs (Table 3). Pre-harvest protection benefits 291 for targeted fish abundance varied with compliance, fishing pressure outside, time closed or 
292 years since establishment (Fig.2, Table S6). PHCs with high compliance or high fishing pressure 293 outside provided pre-harvest benefits in abundance (Fig. 2). The pre-harvest protection benefit 294 for abundance increased by $6 \%$ per year since establishment and $19 \%$ per year since previous 295 harvest (Years Established: $\mathrm{SE}=0.024 ; P<0.01$; Time Closed: $\mathrm{SE}=0.037 ; P<0.001)$. Pre296 harvest protection benefits for targeted fish biomass varied with compliance or PHC size. PHCs 297 with high compliance provided pre-harvest protection benefits in targeted biomass (Fig. 2). Pre298 harvest protection benefits in targeted biomass increased by $15 \%$ per $\mathrm{km}^{2}$ of $\mathrm{PHC}(\mathrm{SE}=0.045 ; \mathrm{P}$ $299<0.01$ ). On average PHCs did not provide pre-harvest protection benefits for non-targeted 300 abundance or biomass, although this result was heterogeneous (Table 3). However, none of the 301 co-variates explained this heterogeneity (Table S7; Fig. S1).

302

303

304

305

306

307

308

309

310

311

312

\section{Harvest benefits}

On average there were harvest benefits with a $21 \%$ greater removal of abundance and $49 \%$ greater removal of biomass of targeted species within the PHC compared to open areas during harvest events, though results were heterogeneous suggesting variation across PHCs (Table 3). Harvest benefits for targeted fish abundance varied with compliance, fishing pressure outside, PHC harvest effort, size, or the time closed since the previous harvest (Table S6; Fig. 2). PHCs with low compliance, high harvest effort or high fishing pressure outside resulted in greater harvest benefits for targeted abundance (Fig. 2). Harvest benefits in targeted abundance increased by $6 \%$ per $\mathrm{km}^{2}$ of $\mathrm{PHC}(\mathrm{SE}=0.017 ; P=0.001)$ and $11 \%$ for each year since the previous harvest $(\mathrm{SE}=0.042 ; P=0.01)$. Harvest benefits for targeted fish biomass varied with compliance, fishing pressure outside, PHC harvest effort, size or years established (Table S6; 
313 Fig. 2). PHCs with high compliance, high harvest effort or high fishing pressure outside, 314 provided harvest benefits for targeted biomass (Fig. 2). Harvest benefits in targeted biomass 315 increased by $18 \%$ per $\mathrm{km}^{2}$ of $\mathrm{PHC}(\mathrm{SE}=0.033 ; P<0.001)$ and $11 \%$ for each year since 316 establishment $(\mathrm{SE}=0.046 ; P=0.016)$. On average PHCs did not provide harvest benefits for 317 non-targeted abundance or biomass, although biomass results were heterogeneous (Table 3). 318 Harvest benefits in non-targeted species increased by $11 \%$ per $\mathrm{km}^{2}$ of $\mathrm{PHC}(\mathrm{SE}=0.047 ; P=$ 319 0.019; Table S7; Fig. S1).

321 Post-harvest protection benefits

322 On average PHCs provided post-harvest protection benefits to targeted fish abundance, with a $32314 \%$ greater abundance when compared to open areas (Table 3). This result was homogenous, 324 suggesting consistency across PHCs. In contrast, there were no post-harvest protection benefits 325 in the biomass of targeted species within PHCs compared to open areas, however, heterogeneity 326 suggests this varied across PHCs (Table 3). Post-harvest protection benefits for targeted fish 327 biomass varied with fishing pressure outside the PHC (Table S6; Fig. 2). When the fishing 328 pressure outside was high, post-harvest benefits in targeted biomass were greater within open 329 areas; when fishing pressure outside was low, post-harvest benefits in targeted biomass were 330 greater within PHCs (Fig. 2). On average PHCs did not provide post-harvest protection benefits 331 for non-targeted abundance or biomass. Although this result was heterogeneous (Table 3), none 332 of the co-variates explained this heterogeneity (Table S7; Fig. S1). 


\section{Discussion}

334 Overall, PHCs provided pre-harvest protection benefits including a 48\% greater abundance and 335 $92 \%$ greater biomass of targeted species compared with areas open to fishing. This supports our

336 hypothesis that PHCs are capable of providing pre-harvest benefits through an increased 337 abundance and biomass of targeted species, despite historical harvesting. However, we were not 338 able to account for migration/movement of targeted species across PHC boundaries, which 339 differs among target species (Nash et al. 2015) and is therefore likely to have contributed to the 340 variability in results across PHCs (Eggleston \& Parsons 2008). Regardless of the mechanism, 341 greater abundance and biomass of fish in PHCs translated to harvest benefits where fishers 342 removed an average of $29 \%$ of the abundance and $49 \%$ of the biomass, a result likely due to 343 greater catch efficiency associated with decreased wariness of targeted fishes within PHCs 344 (Feary et al. 2011; Januchowski-Hartley, Cinner \& Graham 2014; Goetze et al. 2017). Therefore 345 PHCs are a particularly effective fisheries management strategy for increasing short-term 346 fisheries yields from single harvest events. The long-term effectiveness of this strategy will 347 depend on whether there is sufficient recovery time between harvests (Cohen \& Foale 2013; 348 Abesamis et al. 2014; Goetze et al. 2016), and whether increased abundance/biomass can be 349 sustained indefinitely. The high frequency of harvests from many Melanesian PHCs raises 350 concerns about the ability of PHCs to achieve long-term management objectives that relate to 351 maintaining or increasing: sustainable yield and profit; reproductive capacity of fisheries; 352 biodiversity and ecosystem function (Jupiter et al. 2014). A complementary suite of fisheries 353 management and conservation strategies (e.g., NTMRs, gear restrictions, catch limits) in 354 conjunction with PHCs will likely be required to achieve these goals (Jupiter et al. 2017). 
355 PHCs subject to highly intensive pulse fishing events that reduce more than $50 \%$ of standing fish 356 stocks may take between 5-20 years to fully recover (Abesamis et al. 2014). Empirical evidence 357 from PHCs in Fiji shows that 1 year of recovery is insufficient and at least 3 years of closure 358 between harvests is recommended to restore fish abundance and biomass to pre-harvest levels 359 (Goetze et al. 2016). Given the average closure time of study PHCs here was $<2$ years, it is 360 unlikely that biomass within PHCs will recover to pre-harvest levels before the next harvest. 361 This suggests that PHCs experiencing high harvest intensity may not be suitable as a long term 362 fisheries management or conservation strategy for large, long lived taxa (Cohen \& Foale 2013; 363 Goetze et al. 2016). In order to improve the recovery potential within PHCs, harvest benefits 364 may need to be restricted to $\leq 10 \%$ of the standing biomass (Abesamis et al. 2014), with harvest 365 effort restricted to low vulnerability (fast growing and abundant) species and/or longer closure 366 times between harvest events (Goetze et al. 2016). We observed post-harvest protection benefits 367 for abundance and not biomass, which is likely due to the preferential targeting of larger fishes 368 during harvests, generating a greater impact on biomass levels. The prompt removal of large 369 individuals during harvests may reduce the reproductive output of PHCs and limit benefits of 370 larval or adult spillover that are seen in NTMRs (Abesamis \& Russ 2005; Halpern, Lester \& 371 Kellner 2009; Harrison et al. 2012).

372 Variability in post-harvest benefits of PHCs was primarily attributable to the size, age, 373 compliance or outside fishing pressure, four key features shown to influence conservation 374 benefits of NTMRs (Guidetti et al. 2008; McClanahan et al. 2009; Edgar et al. 2014). Limited 375 PHC replicates meant we assessed the influence of these variables independently, nonetheless 
376 our findings are consistent with the NTMR literature (Claudet et al. 2008; Vandeperre et al. 377 2011; Edgar et al. 2014), where protection benefits of PHCs generally increased with size, years 378 since establishment, time since the previous harvest and compliance with fishing restrictions. 379 However, unlike NTMRs, PHCs have had a history of harvesting suggesting that periods of 380 closure were providing some cumulative benefit. To assess protection benefits, PHC boundaries 381 need to be large enough to incorporate adequate site replication. This resulted in the average size 382 of PHCs assessed here $\left(2.7 \mathrm{~km}^{2}\right)$ being larger than the average for the western Pacific (Govan 383 2009; Cohen \& Foale 2013). This limitation coupled with our result of increasing benefits as the 384 size of PHCs increase, suggests that larger PHCs need to be established. PHCs have also been 385 promoted as an alternative to NTMRs due to greater compliance, yet our results suggest that pre386 harvest protection and harvest benefits vary due to compliance, suggesting PHCs are not the 387 solution to poor compliance with other management strategies. An increase in the size or age of 388 PHCs also resulted in a greater harvest benefits, suggesting increased availability of fish stocks 389 in larger, older PHCs generates greater yields during harvests. However, increased harvest 390 benefits may also result from a failure to shut down harvests once pre-determined catch targets 391 are achieved (Jupiter et al. 2012), emphasising the importance of setting and enforcing strict 392 deadlines for the cessation of fishing within PHCs in order to prevent overfishing.

393 PHCs with high fishing pressure outside of their boundaries generally performed better in terms 394 of benefits with increased abundance. Similar findings from studies comparing permanent 395 reserves with fished areas suggest closures are most effective in areas where overfishing is 396 occurring (Hart 2003; Hilborn et al. 2004; Gaines et al. 2010). In contrast, the same result was 
397 not evident with the biomass data which may relate to larger-bodied fish moving over larger 398 areas (Nash et al. 2015) and being more likely to transcend PHC boundaries where they are 399 susceptible to fishing. High fishing pressure outside of PHCs also resulted in a greater proportion 400 of both the abundance and biomass being removed from the PHC during harvests. This is likely 401 due to an increased reliance of the resources within PHCs in areas where fish stocks in open 402 areas have already been depleted (Cohen, Cinner \& Foale 2013). It is therefore important that 403 communities with high levels of fishing or depleted fish stocks do not rely on PHCs as their sole 404 form of management.

405 The effect of compliance on harvest benefits was inconsistent, with a greater proportion of 406 biomass being removed where compliance was high and a greater proportion of abundance 407 removed where compliance was low. Fishers typically target larger-bodied fish (Graham et al. 408 2005) and depletion of larger species within PHC boundaries where compliance is low reduces 409 the biomass available at harvesting. Consequently, harvests in these PHC rely on catching a large 410 number of smaller fish and have a greater impact on abundance than biomass. Similarly, the 411 removal of larger individuals during harvest in areas where compliance was high would naturally 412 have a greater impact on biomass than abundance. These finding support the theory that PHCs 413 are most suitable for short lived, fast growing species (Cohen \& Foale 2013; Goetze et al. 2016) 414 and highlights the importance of examining life history traits in conjunction with recovery data 415 (Cheung, Pitcher \& Pauly 2005; Abesamis et al. 2014).

416 To adequately assess the conservation benefits of PHCs, a study design with a PHC and NTMR 417 of comparable size, habitat and in the same locality is required. NTMRs are a valuable tool for 
418 assessing management strategies (Langlois, Harvey \& Meeuwig 2012), and future research

419 should focus on areas where both NTMR and PHCs occur. To assess long-term conservation and 420 fisheries management objectives, temporal data through multiple harvest events and recovery 421 trajectories will be required. Collecting such data is complicated by haphazard harvest schedules 422 designed to meet the needs of communities rather than researchers, requiring considerable liaison 423 with local communities.

424 We recommend future research focus on collecting data from an array of PHCs with different 425 harvest histories and physical attributes, using the analytical framework outlined here to survey 426 over multiple harvest events. Increasing study locations will improve capacity to assess 427 interactions between covariates and understand their influence on harvest dynamics. Further 428 studies that focus on post-harvest recovery and recovery of pre-harvest protection over 429 standardised time scales such as Goetze et al. (2016), will provide valuable insight and 430 recommendations for harvesting regimes. However, in Melanesia where PHCs are common, 431 small-scale fisheries are often essential for livelihood, meaning these communities cannot afford 432 such delays in management advice that may help sustain their fisheries. To overcome this issue, 433 empirical data could be combined with population modelling to assess the potential of PHCs for 434 long term sustainability of fish stocks and conservation (Carvalho et al. 2015). This would also 435 allow for the assessment of long-term fisheries benefits and whether effort displacement 436 following PHC implementation may lead to overharvesting in the nearby areas open to fishing, 437 an issue that is currently in debate with rotational fisheries (Game et al. 2009; Kaplan, Hart \& 438 Botsford 2010; Plagányi et al. 2015a; b; Purcell et al. 2015). 
439 Our results provide the first comprehensive synthesis of empirical data on the effectiveness of 440 PHCs as a fisheries management and conservation strategy. Despite concerns over the long term 441 value of PHCs, we found that they were capable of increasing fish stocks pre-harvest, indicating 442 that abundance and biomass can accumulate within PHCs. Harvesting of PHCs, however, 443 resulted in rapid decline of the fish stocks, suggesting fisheries and conservation benefits 444 associated with protecting high biomass and abundance will fluctuate and may not be 445 sustainable. To increase the build-up in fish stocks and maximise potential for long term benefits 446 we recommend PHCs be closed to fishing for as long as possible, be as large as possible and 447 compliance encouraged via community engagement and enforcement when necessary. When 448 harvested, overfishing can be prevented by setting and not exceeding strict deadlines or goals.

449 Authors' contributions: This manuscript was developed during a workshop organised by JSG 450 and TJL and attended by all authors. JSG completed the literature review, data selection/quality 451 analysis. JSG and SDJ collected/analysed data from 5 of the 10 studies included in the meta452 analysis. All authors worked on the statistical analysis under the guidance of JC. JSG, SDJ and 453 RW wrote the first draft of the manuscript with all authors contributing to revisions. All authors 454 gave final approval for publication.

\section{Acknowledgments}

457 This study was conducted with funding from the School of Plant Biology at The University of 458 Western Australia (UWA) and grants (2012-38137, 2014-39332) to the Wildlife Conservation 

workshop. RW acknowledges funding support from the Australian Research Council.

\section{Data accessibility}

Data associated with this paper is available as the "Fiji Periodically Harvested Closures Project" in the GlobalArchive repository at http://globalarchive.org/geodata/explore/ (Goetze et al. 2017).

\section{References}

467

468

469

470

471

472

473

474

475

476

477

478

479

480

481

482

483

484

485

486

Abesamis, R.A., Green, A.L., Russ, G.R. \& Jadloc, C.R.L. (2014) The intrinsic vulnerability to fishing of coral reef fishes and their differential recovery in fishery closures. Reviews in Fish Biology and Fisheries, 24, 1033-1063.

Abesamis, R.A. \& Russ, G.R. (2005) Density-dependent spillover from a marine reserve: long-term evidence. Ecological Applications, 15, 1798-1812.

Alcala, A.C., Russ, G.R., Maypa, A.P. \& Calumpong, H.P. (2005) A long-term, spatially replicated experimental test of the effect of marine reserves on local fish yields. Canadian Journal of Fisheries and Aquatic Sciences, 62, 98-108.

Bartlett, C.Y., Manua, C., Cinner, J., Sutton, S., Jimmy, R., South, R., Nilsson, J. \& Raina, J. (2009) Comparison of outcomes of permanently closed and periodically harvested coral reef reserves. Conservation Biology, 23, 1475-1484.

Bell, J.D., Kronen, M., Vunisea, A., Nash, W.J., Keeble, G., Demmke, A., Pontifex, S. \& Andréfouët, S. (2009) Planning the use of fish for food security in the Pacific. Marine Policy, 33, 64-76.

Carvalho, P., Jupiter, S.D., Januchowski-Hartley, F.A., Goetze, J.G., Claudet, J., Langlois, T. \& White, C. (2015) Periodically harvested closures: potentially optimal fisheries management strategies., p. Montpellier, France.

Cheung, W.W., Pitcher, T.J. \& Pauly, D. (2005) A fuzzy logic expert system to estimate intrinsic extinction vulnerabilities of marine fishes to fishing. Biological conservation, 124, 97-111.

Cinner, J., Marnane, M.J., McClanahan, T.R. \& Almany, G.R. (2006) Periodic closures as adaptive coral reef management in the Indo-Pacific. Ecology and Society, 11, 31. 
487

488

489

490

491

492

493

494

495

496

497

498

499

500

501

502

503

504

505

506

507

508

509

510

511

512

513

514

515

516

517

518

519

520

521

Claudet, J., Osenberg, C.W., Benedetti-Cecchi, L., Domenici, P., García-Charton, J.-A., Pérez-Ruzafa, Á., Badalamenti, F., Bayle-Sempere, J., Brito, A., Bulleri, F., Culioli, J.-M., Dimech, M., Falcón, J.M., Guala, I., Milazzo, M., Sánchez-Meca, J., Somerfield, P.J., Stobart, B., Vandeperre, F., Valle, C. \& Planes, S. (2008) Marine reserves: size and age do matter. Ecology Letters, 11, 481489.

Claudet, J., Osenberg, C.W., Domenici, P., Badalamenti, F., Milazzo, M., Falcón, J.M., Bertocci, I., Benedetti-Cecchi, L., García-Charton, J.A., Goñi, R. \& others. (2010) Marine reserves: fish life history and ecological traits matter. Ecological applications, 20, 830-839.

Cohen, P.J. \& Alexander, T.J. (2013) Catch rates, composition and fish size from reefs managed with periodically-harvested closures. PLoS ONE, 8, e 73383.

Cohen, P.J., Cinner, J.E. \& Foale, S. (2013) Fishing dynamics associated with periodically harvested marine closures. Global Environmental Change, 23, 1702-1713.

Cohen, P.J. \& Foale, S.J. (2013) Sustaining small-scale fisheries with periodically harvested marine reserves. Marine Policy, 37, 278-287.

Cohen, P.J. \& Steenbergen, D.J. (2015) Social dimensions of local fisheries co-management in the Coral Triangle. Environmental Conservation, 1-11.

Côté, I.M., Mosqueira, I. \& Reynolds, J.D. (2001) Effects of marine reserve characteristics on the protection of fish populations: a meta-analysis. Journal of Fish Biology, 59, 178-189.

Daw, T.M., Coulthard, S., Cheung, W.W., Brown, K., Abunge, C., Galafassi, D., Peterson, G.D., McClanahan, T.R., Omukoto, J.O. \& Munyi, L. (2015) Evaluating taboo trade-offs in ecosystems services and human well-being. Proceedings of the National Academy of Sciences, 201414900.

Edgar, G.J., Stuart-Smith, R.D., Willis, T.J., Kininmonth, S., Baker, S.C., Banks, S., Barrett, N.S., Becerro, M.A., Bernard, A.T.F., Berkhout, J., Buxton, C.D., Campbell, S.J., Cooper, A.T., Davey, M., Edgar, S.C., Försterra, G., Galván, D.E., Irigoyen, A.J., Kushner, D.J., Moura, R., Parnell, P.E., Shears, N.T., Soler, G., Strain, E.M.A. \& Thomson, R.J. (2014) Global conservation outcomes depend on marine protected areas with five key features. Nature, 506, 216-220.

Eggleston, D.B. \& Parsons, D.M. (2008) Disturbance-induced 'spill-in' of Caribbean spiny lobster to marine reserves. Marine Ecology Progress Series, 371, 213-220.

Feary, D.A., Cinner, J.E., Graham, N.A. \& Januchowski-Hartley, F.A. (2011) Effects of customary marine closures on fish behavior, spear-fishing success, and underwater visual surveys. Conservation Biology, 25, 341-349.

Foale, S. \& Manele, B. (2004) Social and political barriers to the use of marine protected areas for conservation and fishery management in Melanesia. Asia Pacific Viewpoint, 45, 373-386.

Froese, R. \& Pauly, D. (2015) FishBase, http://www.fishbase.org/ 
Gaines, S.D., White, C., Carr, M.H. \& Palumbi, S.R. (2010) Designing marine reserve networks for both conservation and fisheries management. Proceedings of the National Academy of Sciences, 107, $18286-18293$.

Game, E.T., Bode, M., McDonald-Madden, E., Grantham, H.S. \& Possingham, H.P. (2009) Dynamic marine protected areas can improve the resilience of coral reef systems. Ecology Letters, 12, $1336-1346$.

Goetze, J.S., Claudet, J., Januchowski-Hartley, F., Langlois, T., Wilson, S.K., White, C., Weeks, R. \& Jupiter, S.D. (2017) Data from: Demonstrating multiple benefits from periodically harvested fisheries closures. GlobalArchive Repository. http://globalarchive.org/geodata/explore/

Goetze, J.S., Januchowski-Hartley, F.A., Claudet, J., Langlois, T.J., Wilson, S.K. \& Jupiter, S.D. (2017) Fish wariness is a more sensitive indicator to changes in fishing pressure than abundance, length or biomass. Ecological Applications.

Goetze, J.S., Jupiter, S.D., Langlois, T.J., Wilson, S.K., Harvey, E.S., Bond, T. \& Naisilisili, W. (2015) Diver operated video most accurately detects the impacts of fishing within periodically harvested closures. Journal of Experimental Marine Biology and Ecology, 462, 74-82.

Goetze, J.S., Langlois, T., Claudet, J., Januchowski-Hartley, F. \& Jupiter, S.D. (2016) Periodically harvested closures require full protection of vulnerable species and longer closure periods. Biological Conservation, 203, 67-74.

Govan, H. (2009) Achieving the potential of locally managed marine areas in the South Pacific. SPC Traditional Marine Resource Management and Knowledge Information Bulletin, 25, 16-25.

Graham, N.A.J., Dulvy, N.K., Jennings, S. \& Polunin, N.V.C. (2005) Size-spectra as indicators of the effects of fishing on coral reef fish assemblages. Coral Reefs, 24, 118-124.

Guidetti, P., Milazzo, M., Bussotti, S., Molinari, A., Murenu, M., Pais, A., Spanò, N., Balzano, R., Agardy, T., Boero, F., Carrada, G., Cattaneo-Vietti, R., Cau, A., Chemello, R., Greco, S., Manganaro, A., Notarbartolo di Sciara, G., Russo, G.F. \& Tunesi, L. (2008) Italian marine reserve effectiveness: Does enforcement matter? Biological Conservation, 141, 699-709.

Halpern, B.S. (2003) The impact of marine reserves: do reserves work and does reserve size matter? Ecological Applications, 13, 117-137.

Halpern, B.S., Lester, S.E. \& Kellner, J.B. (2009) Spillover from marine reserves and the replenishment of fished stocks. Environmental Conservation, 36, 268-276.

Harrison, H.B., Williamson, D.H., Evans, R.D., Almany, G.R., Thorrold, S.R., Russ, G.R., Feldheim, K.A., van Herwerden, L., Planes, S., Srinivasan, M., Berumen, M.L. \& Jones, G.P. (2012) Larval export from marine reserves and the recruitment benefit for fish and fisheries. Current Biology, 22, 1023-1028.

Hart, D.R. (2003) Yield-and biomass-per-recruit analysis for rotational fisheries, with an application to the Atlantic sea scallop (Placopecten magellanicus). Fishery Bulletin, 101, 44-57. 
Hedges, L.V., Gurevitch, J. \& Curtis, P.S. (1999) The Meta-Analysis of Response Ratios in Experimental Ecology. Ecology, 80, 1150-1156.

Hedges, L.V. \& Pigott, T.D. (2004) The Power of Statistical Tests for Moderators in Meta-Analysis. Psychological Methods, 9, 426-445.

Hilborn, R., Stokes, K., Maguire, J.-J., Smith, T., Botsford, L.W., Mangel, M., Orensanz, J., Parma, A., Rice, J., Bell, J., Cochrane, K.L., Garcia, S., Hall, S.J., Kirkwood, G.P., Sainsbury, K., Stefansson, G. \& Walters, C. (2004) When can marine reserves improve fisheries management? Ocean \& Coastal Management, 47, 197-205.

Holmes, T.H., Wilson, S.K., Travers, M.J., Langlois, T.J., Evans, R.D., Moore, G.I., Douglas, R.A., Shedrawi, G., Harvey, E.S. \& Hickey, K. (2013) A comparison of visual-and stereo-video based fish community assessment methods in tropical and temperate marine waters of Western Australia. Limnol. Oceanogr.: Methods, 11, 337-350.

Januchowski-Hartley, F.A., Cinner, J.E. \& Graham, N.A.J. (2014) Fishery benefits from behavioural modification of fishes in periodically harvested fisheries closures. Aquatic Conservation: Marine and Freshwater Ecosystems, 24, 777-790.

Johannes, R.E. (2002) The renaissance of community-based marine resource management in Oceania. Annual Review of Ecology and Systematics, 317-340.

Jupiter, S.D., Cohen, P.J., Weeks, R., Tawake, A. \& Govan, H. (2014) Locally-managed marine areas: multiple objectives and diverse strategies. Pacific Conservation Biology, 20, 165-179.

Jupiter, S.D. \& Egli, D.P. (2011) Ecosystem-based management in Fiji: successes and challenges after five years of implementation. Journal of Marine Biology, 2011, e940765.

Jupiter, S.D., Epstein, G., Ban, N.C., Mangubhai, S., Fox, M. \& Cox, M. (2017) A Social-Ecological Systems Approach to Assessing Conservation and Fisheries Outcomes in Fijian Locally Managed Marine Areas. Society \& Natural Resources, 0, 1-16.

Jupiter, S.D., Weeks, R., Jenkins, A.P., Egli, D.P. \& Cakacaka, A. (2012) Effects of a single intensive harvest event on fish populations inside a customary marine closure. Coral Reefs, 31, 321-334.

Kaplan, D.M., Hart, D.R. \& Botsford, L.W. (2010) Rotating spatial harvests and fishing effort displacement: a comment on Game et al. (2009). Ecology Letters, 13, E10-E12.

Langlois, T.J., Harvey, E.S. \& Meeuwig, J.J. (2012) Strong direct and inconsistent indirect effects of fishing found using stereo-video: Testing indicators from fisheries closures. Ecological Indicators, 23, 524-534.

Lester, S., Halpern, B., Grorud-Colvert, K., Lubchenco, J., Ruttenberg, B., Gaines, S., Airamé, S. \& Warner, R. (2009) Biological effects within no-take marine reserves: a global synthesis. Marine Ecology Progress Series, 384, 33-46. 
McClanahan, T.R., Graham, N.A., Wilson, S., Letourner, Y. \& Fisher, R. (2009) Effects of fisheries closure size, age, and history of compliance on coral reef fish communities in the western Indian Ocean. Marine Ecology Progress Series, 396, 99-109.

Molloy, P.P., McLean, I.B. \& Côté, I.M. (2009) Effects of marine reserve age on fish populations: a global meta-analysis. Journal of Applied Ecology, 46, 743-751.

Mora, C., Myers, R.A., Coll, M., Libralato, S., Pitcher, T.J., Sumaila, R.U., Zeller, D., Watson, R., Gaston, K.J. \& Worm, B. (2009) Management effectiveness of the world's marine fisheries. PLoS Biol, 7, e1000131.

Nash, K.L., Welsh, J.Q., Graham, N.A. \& Bellwood, D.R. (2015) Home-range allometry in coral reef fishes: comparison to other vertebrates, methodological issues and management implications. Oecologia, 177, 73-83.

Newton, K., Côté, I.M., Pilling, G.M., Jennings, S. \& Dulvy, N.K. (2007) Current and future sustainability of island coral reef fisheries. Current Biology, 17, 655-658.

Pauly, D., Watson, R. \& Alder, J. (2005) Global trends in world fisheries: impacts on marine ecosystems and food security. Philosophical Transactions of the Royal Society of London B: Biological Sciences, 360, 5-12.

Plagányi, É.E., Skewes, T., Haddon, M., Murphy, N., Pascual, R. \& Fischer, M. (2015a) Reply to Purcell et al.: Fishers and science agree, rotational harvesting reduces risk and promotes efficiency. Proceedings of the National Academy of Sciences, 112, E6264-E6264.

Plagányi, É.E., Skewes, T., Murphy, N., Pascual, R. \& Fischer, M. (2015b) Crop rotations in the sea: Increasing returns and reducing risk of collapse in sea cucumber fisheries. Proceedings of the National Academy of Sciences, 112, 6760-6765.

Purcell, S.W., Uthicke, S., Byrne, M. \& Eriksson, H. (2015) Rotational harvesting is a risky strategy for vulnerable marine animals. Proceedings of the National Academy of Sciences, 112, E6263E6263.

R Core Team. (2014) R: A Language and Environment for Statistical Computing. R Foundation for Statistical Computing, Vienna, Austria.

Rassweiler, A., Costello, C. \& Siegel, D.A. (2012) Marine protected areas and the value of spatially optimized fishery management. Proceedings of the National Academy of Sciences, 109, 11884 11889.

Russ, G.R. \& Alcala, A.C. (2003) Marine reserves: Rates and patterns of recovery and decline of predatory fish, 1983-2000. Ecological Applications, 13, 1553-1565.

Valderrama, D. \& Anderson, J.L. (2007) Improving utilization of the Atlantic sea scallop resource: an analysis of rotational management of fishing grounds. Land Economics, 83, 86-103. 
626

627

628

629

630

631

632

633

634

635

636

637

638

639

640

641

642

643

644

Vandeperre, F., Higgins, R.M., Sánchez-Meca, J., Maynou, F., Goñi, R., Martín-Sosa, P., Pérez-Ruzafa, A., Afonso, P., Bertocci, I., Crec'hriou, R., D’Anna, G., Dimech, M., Dorta, C., Esparza, O., Falcón, J.M., Forcada, A., Guala, I., Le Direach, L., Marcos, C., Ojeda-Martínez, C., Pipitone, C., Schembri, P.J., Stelzenmüller, V., Stobart, B. \& Santos, R.S. (2011) Effects of no-take area size and age of marine protected areas on fisheries yields: a meta-analytical approach. Fish and Fisheries, 12, 412-426.

Viechtbauer, W. (2010) The Metafor Package: A Meta-Analysis Package for R.

Supporting information

Additional Supporting Information may be found online in the supporting information tab for this article:

Table S1: Single and combined search terms used in the literature review

Table S2: Methods, experimental design and species selection for each PHC study.

Table S3: Fishing pressure, compliance, harvest intensity for each PHC.

Table S4: Targeted/non-targeted species for each PHC.

Table S5: Correlations between moderators

Table S6: Results of tests for model heterogeneity for targeted species.

Table S7: Results of tests for model heterogeneity for non-targeted species.

Fig. S1: The influence of categorical co-variates on PHC benefits for non-targeted species. 
Table 1: Benefit and assessment of individual or multiple PHCs. Benefits 1 to 3 were assessed in this manuscript.

\begin{tabular}{|c|c|c|c|c|}
\hline Potential PHC benefit & Hypothesis & Effect size description & Effect size equation & Sampling \\
\hline $\begin{array}{l}\text { 1. Pre-harvest } \\
\text { protection }\end{array}$ & $\begin{array}{l}\text { Abundance and biomass are greater inside PHCs } \\
\text { compared to outside immediately prior to a harvest. }\end{array}$ & $\begin{array}{l}\text { Ratio of inside to outside before } \\
\text { harvests. }\end{array}$ & $E_{b}=P b / O b$ & $\mathrm{CI}$ \\
\hline 2. Harvest & $\begin{array}{l}\text { Harvests remove a larger proportion of the } \\
\text { abundance and biomass within PHCs than outside. }\end{array}$ & $\begin{array}{l}\text { Ratio of after to before in the PHC while } \\
\text { controlling for change outside. }\end{array}$ & $E_{h}=(\mathrm{Pa} / \mathrm{Pb}) /(\mathrm{Oa} / \mathrm{Ob})$ & BACI \\
\hline $\begin{array}{l}\text { 3. Post-harvest } \\
\text { protection }\end{array}$ & $\begin{array}{l}\text { Abundance and biomass remain greater inside } \\
\text { PHCs compared to outside immediately after they } \\
\text { are harvested. }\end{array}$ & Ratio of inside to outside after harvests. & $E_{a}=P a / O a$ & $\mathrm{CI}$ \\
\hline $\begin{array}{l}\text { 4. Post-harvest } \\
\text { recovery }\end{array}$ & $\begin{array}{l}\text { Abundance and biomass are greater inside } \mathrm{PHCs} \\
\text { compared to outside after a certain period of time } \\
\text { after the prior harvest. }\end{array}$ & $\begin{array}{l}\text { Ratio of inside to outside after a certain } \\
\text { period of recovery. }\end{array}$ & $E_{r}=\mathrm{Pr} / \mathrm{Or}$ & $\mathrm{CI}$ \\
\hline $\begin{array}{l}\text { 5. Recovery of pre- } \\
\text { harvest protection }\end{array}$ & $\begin{array}{l}\text { Abundance and biomass within the PHCs after a } \\
\text { certain period of time is equal to or greater than } \\
\text { prior to the harvest. }\end{array}$ & $\begin{array}{l}\text { Ratio of the PHC after a certain period of } \\
\text { recovery to the PHC before the prior } \\
\text { harvest while controlling for change } \\
\text { outside. }\end{array}$ & $\begin{array}{l}E_{p}=(\mathrm{Pr} / \mathrm{Pb}) / \\
(\mathrm{Or} / \mathrm{Ob})\end{array}$ & $\begin{array}{l}\text { Multiple } \\
\text { CI }\end{array}$ \\
\hline $\begin{array}{l}\text { 6. Maintenance of } \\
\text { post-harvest } \\
\text { protection }\end{array}$ & $\begin{array}{l}\text { Abundance and biomass within PHCs immediately } \\
\text { after the subsequent harvest is equal to or greater } \\
\text { than immediately after the prior harvest. }\end{array}$ & $\begin{array}{l}\text { Ratio of the PHC after the subsequent } \\
\text { harvest to the PHC after the prior harvest } \\
\text { while controlling for change outside. }\end{array}$ & $\begin{array}{l}E_{m}=\left(P a_{n+1} / O a_{n+1}\right) \\
/\left(P a_{n} / O a_{n}\right)\end{array}$ & $\begin{array}{l}\text { Multiple } \\
\text { CI }\end{array}$ \\
\hline 7. Conservation & $\begin{array}{l}\text { The pre-harvest protection benefit of PHCs is equal } \\
\text { to or greater than the protection benefit of no-take } \\
\text { marine reserves. }\end{array}$ & $\begin{array}{l}\text { Ratio of inside to outside before } \\
\text { harvests, relative to inside outside no- } \\
\text { take areas (NTMR) in the same area. }\end{array}$ & $\begin{array}{l}E_{c}= \\
(\mathrm{Pb} / \mathrm{Ob}) /(\mathrm{NTMR} / \mathrm{O})\end{array}$ & Beyond CI \\
\hline $\begin{array}{l}\text { 8. Sustainability of } \\
\text { periodic harvest } \\
\text { practice }\end{array}$ & $\begin{array}{l}\text { PHCs benefits are maintained or increased over the } \\
\text { long term. }\end{array}$ & $\begin{array}{l}\text { Slope of the above effect sizes over } \\
\text { multiple harvest cycles. }\end{array}$ & $\begin{array}{l}E_{s}=\mathrm{m} \\
\text { where } \mathrm{Y}=\mathrm{m} * \mathrm{E}_{\mathrm{x}}+\mathrm{b}\end{array}$ & BACIPS \\
\hline
\end{tabular}


Table 2: PHC information and data source for each study case. NA = information not available.

\begin{tabular}{|c|c|c|c|c|c|c|c|c|c|c|}
\hline $\begin{array}{l}\text { PHC } \\
\text { Name }\end{array}$ & Country & $\begin{array}{c}\text { PHC } \\
\text { Size } \\
\left(\mathrm{km}^{2}\right)\end{array}$ & $\begin{array}{c}\text { Years } \\
\text { established }\end{array}$ & Compliance & $\begin{array}{l}\text { Fishing } \\
\text { pressure }\end{array}$ & $\begin{array}{c}\text { Harvest } \\
\text { Time } \\
\text { (Days) }\end{array}$ & $\begin{array}{c}\text { Harvest } \\
\text { effort }\end{array}$ & $\begin{array}{c}\text { Time } \\
\text { closed } \\
\text { when } \\
\text { sampled } \\
\text { (Years) }\end{array}$ & $\begin{array}{c}\text { Historical } \\
\text { Harvest } \\
\text { Regime (at } \\
\text { time of } \\
\text { sampling) }\end{array}$ & Reference \\
\hline Nakodu & Fiji & 0.73 & 3 & High & Low & 4 & High & 3 & $\begin{array}{l}\text { None since } \\
\text { establishment }\end{array}$ & This study \\
\hline Kiobo & Fiji & 2.07 & 3 & Low & Low & 7 & Low & 1 & $\begin{array}{c}\text { Once every } \\
\text { year }\end{array}$ & $\begin{array}{c}\text { (Goetze et al. } \\
\text { 2015) }\end{array}$ \\
\hline Tuatua & Fiji & 1.34 & 8 & High & Low & 1 & Low & 0.25 & $\begin{array}{l}\text { Every three } \\
\text { months }\end{array}$ & This study \\
\hline Natokalau & Fiji & 2.17 & 7 & High & High & 2 & Low & 1 & $\begin{array}{l}\text { Once a year } \\
\text { for the last } 2 \\
\text { years only }\end{array}$ & This study \\
\hline Nauouo & Fiji & 3.69 & 3 & Low & High & 3 & Low & 0.08 & $\begin{array}{l}\text { Twice in } \\
\text { three years }\end{array}$ & This study \\
\hline Muluk & $\begin{array}{l}\text { Papua New } \\
\text { Guinea }\end{array}$ & 0.58 & 10 & High & Low & NA & NA & 0.5 & $\begin{array}{l}\text { Closed 2-3 } \\
\text { times for } 1-2 \\
\text { years over a }\end{array}$ & $\begin{array}{c}\text { (Cinner } \text { et al. } \\
\text { 2006) }\end{array}$ \\
\hline
\end{tabular}




\begin{tabular}{|c|c|c|c|c|c|c|c|c|c|c|}
\hline & & & & & & & & & $\begin{array}{c}10 \text { year time } \\
\text { span }\end{array}$ & \\
\hline Unakap & Vanuatu & 0.14 & 5 & High & Low & 3 & Low & 0.5 & $\begin{array}{l}\text { Once every six } \\
\text { months (not } \\
\text { always for } \\
\text { finfish) }\end{array}$ & $\begin{array}{c}\text { (Januchowski- } \\
\text { Hartley, } \\
\text { Cinner \& } \\
\text { Graham 2014) }\end{array}$ \\
\hline Laonamoa & Vanuatu & 0.16 & 3 & High & Low & 3 & Low & 0.5 & $\begin{array}{l}\text { Once every } 6 \\
\text { months }\end{array}$ & $\begin{array}{c}\text { (Januchowski- } \\
\text { Hartley, } \\
\text { Cinner \& } \\
\text { Graham 2014) }\end{array}$ \\
\hline
\end{tabular}


649 Table 3: Quantification of PHC benefits using log-ratio effect size $\left(E_{b, a, h}\right)$ and tests for total heterogeneity $(Q t)$.

650 Effect sizes with confidence intervals that do not overlap zero and/or significant tests for heterogeneity $(\mathrm{P}(\mathrm{Qt})<$

$6510.05)$ are shown in bold.

\begin{tabular}{|c|c|c|c|c|c|c|}
\hline Benefit & Group & Metric & $\mathrm{E}[95 \% \mathrm{CI}]$ & Qt & $\mathbf{P}(\mathbf{Q t})$ & df \\
\hline \multirow{4}{*}{ Pre-harvest protection } & \multirow{2}{*}{ Targeted } & Abundance & $E_{b}=0.392[0.111 ; 0.673]$ & 50.17 & $<0.0001$ & 9 \\
\hline & & Biomass & $E_{b}=0.654[0.147 ; 1.161]$ & 113.63 & $<0.0001$ & 9 \\
\hline & \multirow{2}{*}{ Non-targeted } & Abundance & $E_{b}=-0.041[-0.239 ; 0.157]$ & 15.5891 & 0.029 & 7 \\
\hline & & Biomass & $E_{b}=-0.0236[-0.531 ; 0.483]$ & 29.45 & $<0.001$ & 7 \\
\hline \multirow{4}{*}{ Harvest } & \multirow{2}{*}{ Targeted } & Abundance & $E_{h}=-0.239[-0.471 ;-0.007]$ & 18.51 & 0.018 & 8 \\
\hline & & Biomass & $E_{h}=-0.671[-1.155 ;-0.187]$ & 30.68 & $<0.001$ & 8 \\
\hline & \multirow{2}{*}{ Non-targeted } & Abundance & $E_{h}=-0.078[-0.325 ; 0.169]$ & 12.56 & 0.083 & 7 \\
\hline & & Biomass & $E_{h}=-0.152[-0.75 ; 0.446]$ & 27.41 & $<0.001$ & 7 \\
\hline \multirow{4}{*}{ Post-harvest protection } & \multirow{2}{*}{ Targeted } & Abundance & $E_{a}=0.134[0.035 ; 0.233]$ & 12.23 & 0.1414 & 8 \\
\hline & & Biomass & $E_{a}=0.012[-0.387 ; 0.411]$ & 69.12 & $<0.0001$ & 8 \\
\hline & \multirow{2}{*}{ Non-targeted } & Abundance & $E_{a}=-0.129[-0.448 ; 0.19]$ & 45.07 & $<0.0001$ & 7 \\
\hline & & Biomass & $E_{a}=-0.07[-0.518 ; 0.378]$ & 52.72 & $<0.0001$ & 7 \\
\hline
\end{tabular}




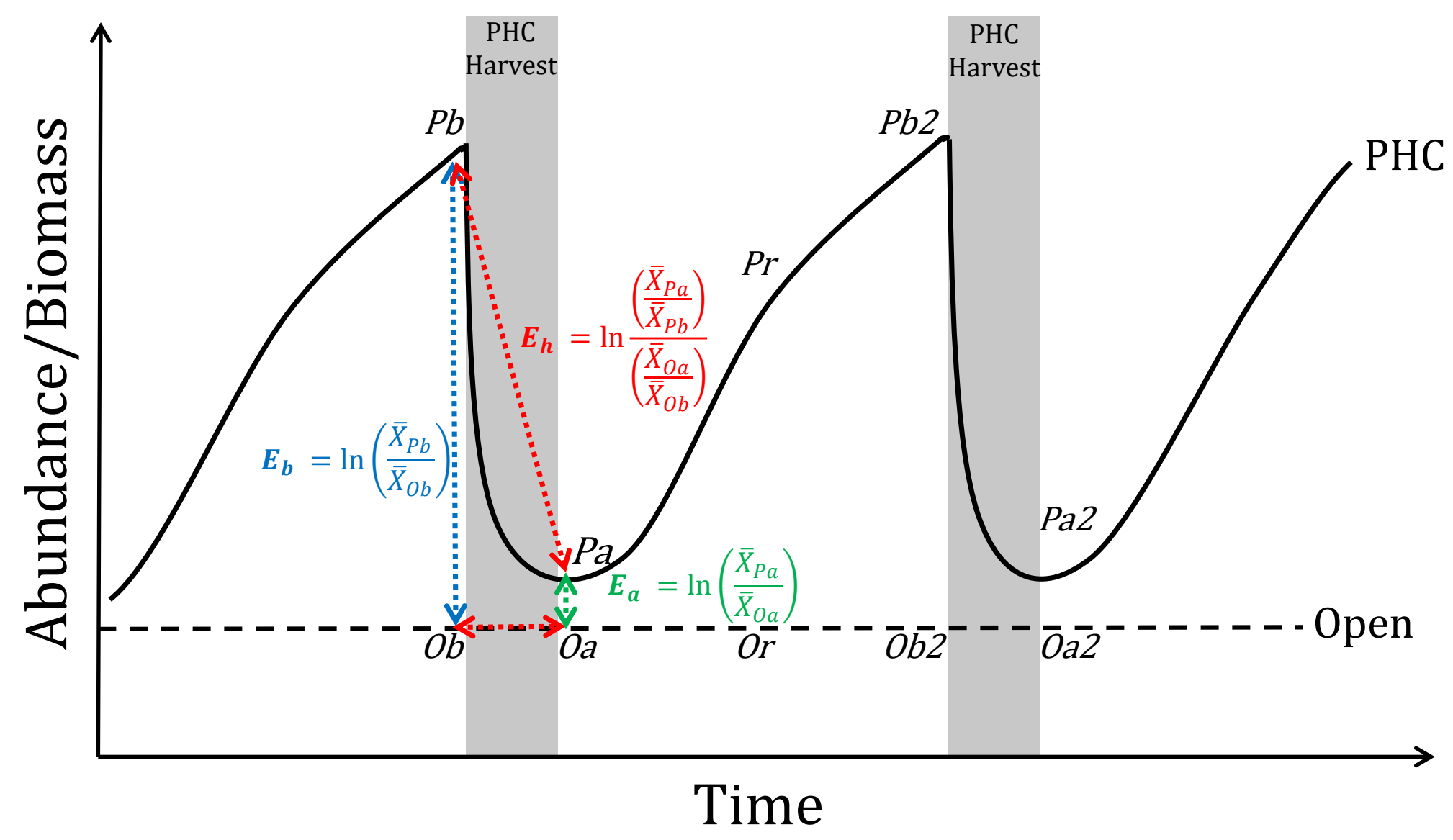




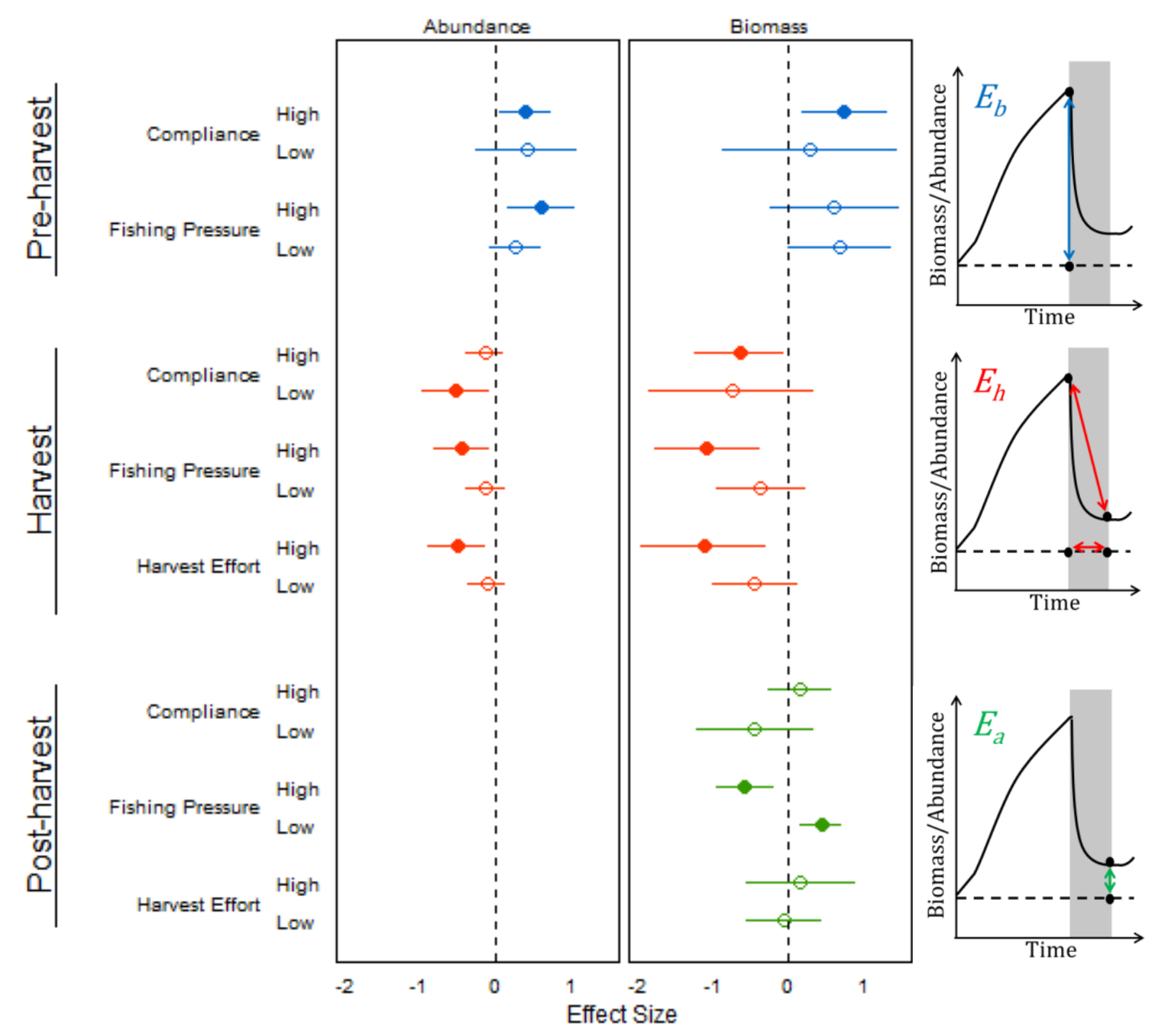


Table S1: Single and combined search terms used in the literature review

\begin{tabular}{ll}
\hline Single Terms & Combined Terms \\
\hline Ra'ui & Periodically Harvested Closure \\
Sasi & Customary Closure AND OR Reserve \\
Rahui & Marine Protected Area \\
Raui & Community-based Closure AND OR Reserve \\
& Rotational Closure \\
& Seasonal Closure \\
& Partially Closed \\
& Temporary Closure OR Reserve \\
& Periodic Fisheries Reserve \\
& Periodic Fisheries Closure \\
& Customary Marine Tenure \\
& Rotative Closure \\
& Tabu Area \\
Taboo Area & Tambu Area \\
& Opening No-take \\
& Removing No-take \\
\hline
\end{tabular}


Table S2: Methods, experimental design and species selection used at each PHC for each study.

\begin{tabular}{|c|c|c|c|c|c|c|c|c|}
\hline \multirow{2}{*}{$\begin{array}{c}\text { PHC } \\
\text { Name }\end{array}$} & \multirow{2}{*}{$\begin{array}{l}\text { Observation } \\
\text { Method }\end{array}$} & \multirow{2}{*}{$\begin{array}{c}\text { Transect } \\
\text { Dimensions }\end{array}$} & \multirow{2}{*}{$\begin{array}{l}\text { Depth } \\
\text { (m) }\end{array}$} & \multicolumn{2}{|c|}{ Sites (Transects) } & \multirow[t]{2}{*}{ Target Species List } & \multirow{2}{*}{$\begin{array}{c}\text { Non-Target Species } \\
\text { List }\end{array}$} & \multirow[t]{2}{*}{ Reference } \\
\hline & & & & PHC & Open & & & \\
\hline Nakodu & $\begin{array}{l}\text { Stereo Diver } \\
\text { Operated Video }\end{array}$ & $50 \times 5 \mathrm{~m}$ Belt & $1-3$ & $3(6)$ & $6(6)$ & $\begin{array}{l}\text { Species caught during harvest } \\
\text { (list below) }\end{array}$ & $\begin{array}{l}\text { Species not caught } \\
\text { during harvest (list } \\
\text { below) }\end{array}$ & This study \\
\hline Kia & UVC & $50 \times 5 \mathrm{~m}$ Belt & $\begin{array}{c}5-8 \text { and } \\
12^{-1} 5\end{array}$ & $4(10)$ & $4(10)$ & $\begin{array}{l}\text { Acanthuridae, Carangidae, } \\
\text { Lethrinidae, Lutjanidae, } \\
\text { Scaridae, Serranidae }\end{array}$ & $\begin{array}{c}\text { Balistidae, } \\
\text { Chaetodontidae, } \\
\text { Pomacanthidae, } \\
\text { Zanclidae }\end{array}$ & $\begin{array}{l}\text { (Jupiter et al. } \\
\text { 2012) }\end{array}$ \\
\hline Kiobo & $\begin{array}{c}\text { Stereo Diver } \\
\text { Operated Video }\end{array}$ & $50 \times 5 \mathrm{~m}$ Belt & $5-8$ & $2(6)$ & $4(6)$ & $\begin{array}{l}\text { Species caught during harvest } \\
\text { (list below) }\end{array}$ & $\begin{array}{l}\text { Species not caught } \\
\text { during harvest (list } \\
\text { below) }\end{array}$ & $\begin{array}{l}\text { (Goetze et al. } \\
\text { 2015) }\end{array}$ \\
\hline Tuatua & $\begin{array}{c}\text { Stereo Diver } \\
\text { Operated Video }\end{array}$ & $50 \times 5 \mathrm{~m}$ Belt & $5-8$ & $3(6)$ & $6(6)$ & $\begin{array}{l}\text { Species caught during harvest } \\
\text { (list below) }\end{array}$ & $\begin{array}{l}\text { Species not caught } \\
\text { during harvest (list } \\
\text { below) }\end{array}$ & This study \\
\hline Sumilon & UVC & $50 \times 20 \mathrm{~m}$ Belt & $2^{-1} 7$ & $1(6)$ & $3(2)$ & $\begin{array}{l}\text { Serranidae, Lutjanidae, } \\
\text { Lethrinidae and Carangidae }\end{array}$ & Not Assessed & $\begin{array}{c}\text { (Russ and } \\
\text { Alcala 2003, } \\
\text { Alcala et al. } \\
\text { 2005) }\end{array}$ \\
\hline Natokalau & $\begin{array}{l}\text { Stereo Diver } \\
\text { Operated Video }\end{array}$ & $50 \times 5 \mathrm{~m}$ Belt & $5-8$ & $6(6)$ & $6(6)$ & $\begin{array}{l}\text { Species caught during harvest } \\
\text { (list below) }\end{array}$ & $\begin{array}{l}\text { Species not caught } \\
\text { during harvest (list } \\
\text { below) }\end{array}$ & This study \\
\hline Nauouo & $\begin{array}{l}\text { Stereo Diver } \\
\text { Operated Video }\end{array}$ & $50 \times 5 \mathrm{~m}$ Belt & $1-3$ & $3(6)$ & $6(6)$ & $\begin{array}{l}\text { Species caught during harvest } \\
\text { (list below) }\end{array}$ & $\begin{array}{l}\text { Species not caught } \\
\text { during harvest (list } \\
\text { below) }\end{array}$ & This study \\
\hline Muluk & UVC & $50 \times 5 \mathrm{~m}$ Belt & $3-7$ & $3(5)$ & $3(5)$ & $\begin{array}{l}\text { Acanthuridae, Balistidae, } \\
\text { Chaetodontidae, Haemulidae, } \\
\text { Labridae, Lethrinidae, } \\
\text { Lutjanidae, Mullidae, } \\
\text { Nemiteridae, Scaridae, } \\
\text { Serranidae, Siganidae }\end{array}$ & Not Assessed & $\begin{array}{l}\text { (Cinner et al. } \\
\text { 2006b) }\end{array}$ \\
\hline Unakap & UVC & $50 \times 5 \mathrm{~m}$ Belt & $5-8$ & $1(8)$ & $1(8)$ & $\begin{array}{l}\text { All fish families of which } \\
\text { more than one individual was } \\
\text { caught during harvests }\end{array}$ & $\begin{array}{l}\text { All remaining species } \\
\text { (not specified) }\end{array}$ & $\begin{array}{l}\text { (Januchowski- } \\
\text { Hartley et al. } \\
\text { 2014) }\end{array}$ \\
\hline Laonamoa & UVC & $50 \times 5 \mathrm{~m}$ Belt & $5^{-1} 0$ & $1(8)$ & $1(8)$ & $\begin{array}{l}\text { All fish families of which } \\
\text { more than one individual was } \\
\text { caught during harvests }\end{array}$ & $\begin{array}{l}\text { All remaining species } \\
\text { (not specified) }\end{array}$ & $\begin{array}{l}\text { (Januchowski- } \\
\text { Hartley et al. } \\
\text { 2014) }\end{array}$ \\
\hline
\end{tabular}


Table S3: The level of fishing pressure outside, compliance with the fishing restriction and intensity of the harvest within each PHC and the information used to determine each category.

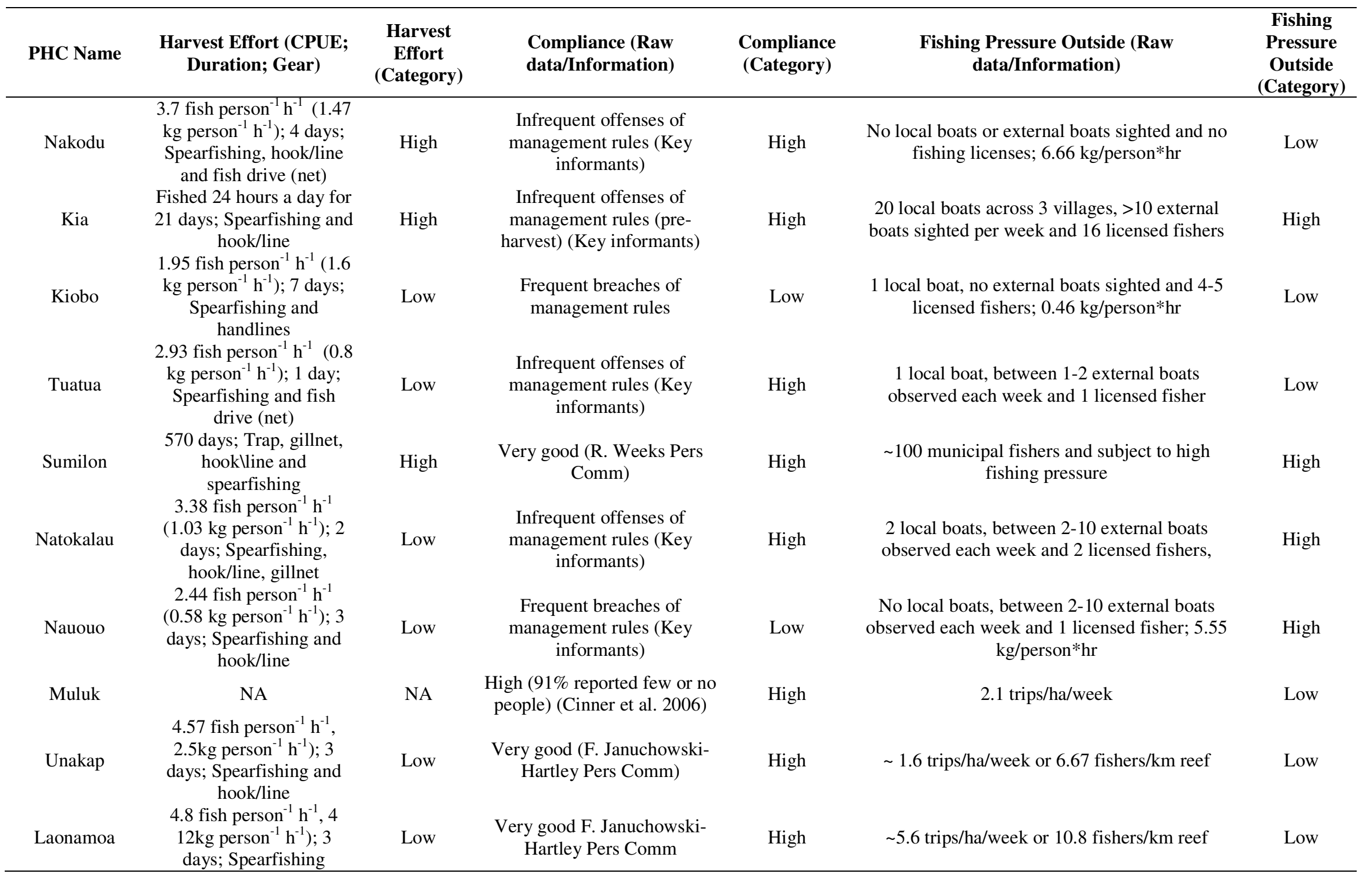


Table S4: Targeted/non-targeted species (and their families) for each PHC in the unpublished data.

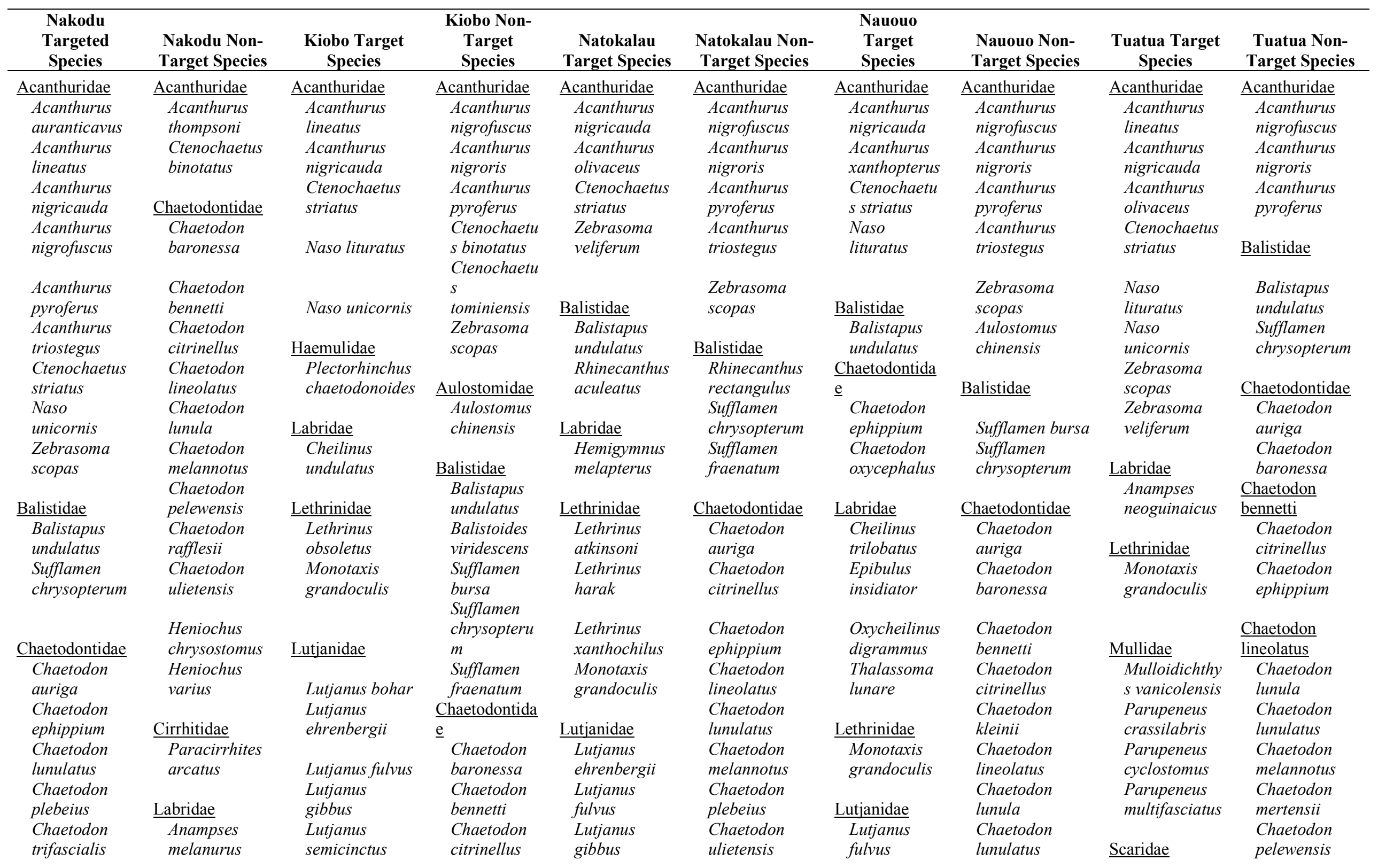




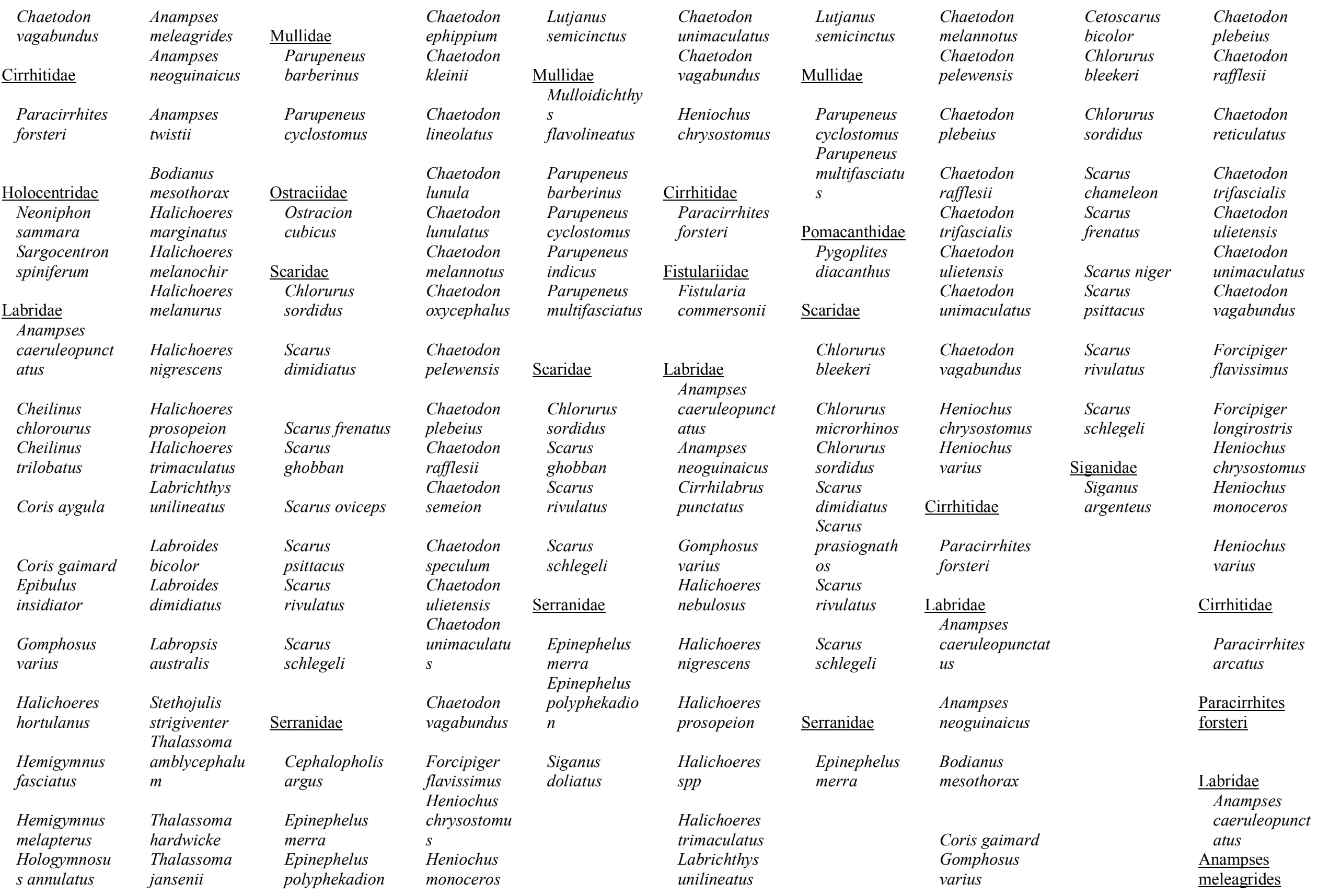




\begin{tabular}{|c|c|c|c|c|}
\hline $\begin{array}{l}\text { Novaculichthy } \\
\text { s taeniourus }\end{array}$ & $\begin{array}{l}\text { Thalassoma } \\
\text { lunare }\end{array}$ & $\begin{array}{l}\text { Plectropomus } \\
\text { laevis } \\
\text { Plectropomus }\end{array}$ & $\begin{array}{l}\text { Heniochus } \\
\text { singularius } \\
\text { Heniochus }\end{array}$ & $\begin{array}{l}\text { Labroides } \\
\text { dimidiatus } \\
\text { Novaculichthy }\end{array}$ \\
\hline Lethrinidae & Monacanthidae & leopardus & varius & s taeniourus \\
\hline $\begin{array}{l}\text { Lethrinus } \\
\text { atkinsoni }\end{array}$ & $\begin{array}{l}\text { Cantherhines } \\
\text { pardalis } \\
\text { Oxymonacant }\end{array}$ & $\begin{array}{l}\text { Plectropomus } \\
\text { pessuliferus }\end{array}$ & Cirrhitidae & $\begin{array}{l}\text { Pseudocheilin } \\
\text { us evanidus }\end{array}$ \\
\hline $\begin{array}{l}\text { Monotaxis } \\
\text { grandoculis }\end{array}$ & $\begin{array}{l}\text { hus } \\
\text { longirostris }\end{array}$ & $\frac{\text { Siganidae }}{\text { Siganus }}$ & $\begin{array}{l}\text { Paracirrhite } \\
\text { s arcatus }\end{array}$ & $\begin{array}{l}\text { Stethojulis } \\
\text { bandanensis } \\
\text { Stethojulis }\end{array}$ \\
\hline $\begin{array}{l}\frac{\text { Lutjanidae }}{\text { Lutjanus }} \\
\text { ehrenbergii }\end{array}$ & $\frac{\text { Nemipteridae }}{\begin{array}{l}\text { Scolopsis } \\
\text { bilineata }\end{array}}$ & $\begin{array}{l}\text { argenteus } \\
\text { Siganus } \\
\text { doliatus }\end{array}$ & $\begin{array}{l}\text { Anampses caeruleopunctatus } \\
\text { Anampses }\end{array}$ & $\begin{array}{l}\text { strigiventer } \\
\text { Thalassoma } \\
\text { hardwicke }\end{array}$ \\
\hline $\begin{array}{l}\text { Lutjanus } \\
\text { fulvus } \\
\text { Lutjanus }\end{array}$ & $\frac{\text { Pomacanthidae }}{\text { Centropyge }}$ & $\begin{array}{l}\text { Siganus } \\
\text { stellatus }\end{array}$ & $\begin{array}{l}\text { geographicu } \\
\text { S } \\
\text { Anampses }\end{array}$ & $\begin{array}{l}\text { Thalassoma } \\
\text { lunare }\end{array}$ \\
\hline gibbus & bicolor & & $\begin{array}{l}\text { meleagrides } \\
\text { Anampses }\end{array}$ & $\underline{\text { Nemipteridae }}$ \\
\hline & Centropyge & & neoguinaicu & Scolopsis \\
\hline$\frac{\text { Mullidae }}{\text { Mulloidichthy }}$ & flavissima & & 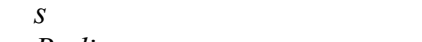 & bilineata \\
\hline $\begin{array}{l}\text { Mulloldichthy } \\
\text { s flavolineatus } \\
\text { Mulloidichthy }\end{array}$ & $\begin{array}{l}\text { Pygoplites } \\
\text { diacanthus }\end{array}$ & & $\begin{array}{l}\text { Bodianus } \\
\text { mesothorax } \\
\text { Cirrhilabrus }\end{array}$ & $\begin{array}{l}\text { Scolopsis } \\
\text { trilineata }\end{array}$ \\
\hline$s$ vanicolensis & & & punctatus & $\underline{\text { Pomacanthidae }}$ \\
\hline $\begin{array}{l}\text { Parupeneus } \\
\text { barberinus }\end{array}$ & & & $\begin{array}{l}\text { Gomphosus } \\
\text { varius }\end{array}$ & $\begin{array}{l}\text { Centropyge } \\
\text { bicolor }\end{array}$ \\
\hline Parupeneus & & & Halichoeres & Centropyge \\
\hline crassilabris & & & prosopeion & bispinosa \\
\hline Parupeneus & & & Labrichthys & Centropyge \\
\hline cyclostomus & & & unilineatus & flavissima \\
\hline Parupeneus & & & Labroides & Pygoplites \\
\hline indicus & & & bicolor & diacanthus \\
\hline $\begin{array}{l}\text { Parupeneus } \\
\text { multifasciatus }\end{array}$ & & & $\begin{array}{l}\text { Labroides } \\
\text { dimidiatus }\end{array}$ & Tetraodontidae \\
\hline Parupeneus & & & Labroides & Canthigaster \\
\hline pleurostigma & & & $\begin{array}{l}\text { pectoralis } \\
\text { Labropsis }\end{array}$ & valentini \\
\hline$\underline{\text { Scaridae }}$ & & & australis & $\underline{\text { Zanclidae }}$ \\
\hline Cetoscarus & & & Pseudocoris & Zanclus \\
\hline bicolor & & & yamashiroi & cornutus \\
\hline Chlorurus & & & Stethojulis & \\
\hline microrhinos & & & strigiventer & \\
\hline Chlorurus & & & Thalassoma & \\
\hline sordidus & & & hardwicke & \\
\hline
\end{tabular}

Halichoeres

chrysus

Halichoeres

hortulanus

Halichoeres

marginatus

Halichoeres

melanochir

Halichoeres

nigrescens

Halichoeres

trimaculatus

Labrichthys

unilineatus

Labroides

bicolor

Labroides

dimidiatus

Macropharyngo

don negrosensis

Novaculichthys

taeniourus

Stethojulis

strigiventer

Stethojulis

trilineata

Thalassoma

hardwicke

Thalassoma

jansenii

Monacanthidae

Amanses scopas

Cantherhines

dumerilii

Oxymonacanthu

s longirostris

Nemipteridae

Scolopsis

bilineata
Anampses

twistii

Bodianus

anthioides

Bodianus

mesothorax

Cirrhilabrus

punctatus

Coris gaimard

Gomphosus

varius

Halichoeres chrysus

Halichoeres

marginatus

Halichoeres

nigrescens

Halichoeres

prosopeion

Halichoeres

trimaculatus

Labrichthys

unilineatus

Labroides

bicolor

Labroides

dimidiatus

Labropsis

australis

Novaculichthy

s taeniourus

Pseudodax

moluccanus

Stethojulis

bandanensis

Stethojulis

strigiventer

Thalassoma

hardwicke

Thalassoma

jansenii 


\begin{tabular}{|c|c|}
\hline & $\begin{array}{l}\text { Thalassoma } \\
\text { iansenii }\end{array}$ \\
\hline $\begin{array}{l}\text { longiceps } \\
\text { Scarus } \\
\text { chameleon }\end{array}$ & $\begin{array}{l}\text { jansenii } \\
\text { Thalassoma } \\
\text { lunare }\end{array}$ \\
\hline Scarus & Monacanthida \\
\hline dimidiatus & $\overline{\mathrm{e}}$ \\
\hline Scarus & Cantherhine \\
\hline $\begin{array}{l}\text { forsteni } \\
\text { Scarus }\end{array}$ & s dumerilii \\
\hline $\begin{array}{l}\text { Scarus } \\
\text { frenatus }\end{array}$ & Nemipteridae \\
\hline $\begin{array}{l}\text { Scarus } \\
\text { ghobban }\end{array}$ & $\begin{array}{l}\text { Scolopsis } \\
\text { bilineata }\end{array}$ \\
\hline $\begin{array}{l}\text { Scarus } \\
\text { globiceps }\end{array}$ & $\frac{\text { Pinguipedidae }}{\text { Parapercis }}$ \\
\hline Scarus niger & hexophtalma \\
\hline Scarus & Pomacanthida \\
\hline oviceps & $\overline{\mathrm{e}}$ \\
\hline $\begin{array}{l}\text { Scarus } \\
\text { prasiognathos }\end{array}$ & $\begin{array}{l}\text { Centropyge } \\
\text { bicolor }\end{array}$ \\
\hline Scarus & Centropyge \\
\hline psittacus & bispinosa \\
\hline Scarus & Centropyge \\
\hline rivulatus & flavissima \\
\hline $\begin{array}{l}\text { Scarus } \\
\text { rivulatus }\end{array}$ & $\begin{array}{l}\text { Pygoplites } \\
\text { diacanthus }\end{array}$ \\
\hline Scarus & Tetraodontida \\
\hline schlegeli & \\
\hline Scarus spinus & $\begin{array}{l}\text { Canthigaste } \\
\text { rvalentini }\end{array}$ \\
\hline erranidae & Zanclidae \\
\hline Epinephelus & $\overline{\text { Zanclus }}$ \\
\hline
\end{tabular}

Scolopsis

trilineata

Pomacanthidae

Centropyge

bicolor

Centropyge

bispinosa

Centropyge

flavissima
Thalassoma

lunare

Thalassoma

lutescens

Monacanthidae Amanses

scopas

Cantherhines

dumerilii

Oxymonacant

hus

longirostris

Nemipteridae

Scolopsis

bilineata

Pinguipedidae

Parapercis

hexophtalma

Pomacanthidae Centropyge bicolor

Centropyge

bispinosa

Centropyge

flavissima

Pygoplites

diacanthus

$\frac{\text { Zanclidae }}{\text { Zanclus }}$

cornutus

Siganidae

Siganus

argenteus

Siganus

spinus 
Table S5: Pearson's $(\rho)$, Cramer's V $(V)$ and Intra-class $(I C)$ correlations between moderators

\begin{tabular}{|c|c|c|c|c|c|c|}
\hline & Compliance & $\begin{array}{c}\text { Fishing Pressure } \\
\text { Outside }\end{array}$ & $\begin{array}{c}\text { PHC Harvest } \\
\text { Effort }\end{array}$ & Size & $\begin{array}{l}\text { Time } \\
\text { Closed } \\
\end{array}$ & $\begin{array}{c}\text { Years } \\
\text { Established }\end{array}$ \\
\hline Compliance & - & & & & & \\
\hline Fishing Pressure Outside & $0.102(V)$ & - & & & & \\
\hline PHC Harvest Effort & $0.378(V)$ & $0.316(V)$ & - & & & \\
\hline Size & $-0.451(I C)$ & $0.268(I C)$ & $0.076(I C)$ & - & & \\
\hline Time Closed & $-0.226(I C)$ & $0.025(I C)$ & $0.525(I C)$ & $-0.175(\rho)$ & - & \\
\hline Years Established & $0.382(I C)$ & $-0.168(I C)$ & $-0.13(I C)$ & $-0.046(\rho)$ & $0.376(\rho)$ & - \\
\hline
\end{tabular}


Table S6: Results of tests for model heterogeneity for targeted species $(*<0.05, * *<0.01, * * *<0.001$ or “_" = not significant). Results are only shown if tests for total heterogeneity $(Q t)$ were significant (see Table 1$)$.

\begin{tabular}{|c|c|c|c|c|c|c|c|}
\hline Benefit & Metric & Compliance & $\begin{array}{c}\text { Fishing Pressure } \\
\text { Outside }\end{array}$ & PHC Harvest Effort & Size & Time Closed & Years Established \\
\hline \multirow{2}{*}{$\begin{array}{c}\text { Pre-harvest } \\
\text { protection }\end{array}$} & Abundance & - & - & Not Relevant & - & $* * *$ & $*$ \\
\hline & Biomass & - & - & Not Relevant & $* *$ & - & - \\
\hline \multirow{2}{*}{ Harvest } & Abundance & - & - & - & $* *$ & $*$ & - \\
\hline & Biomass & - & - & - & $* * *$ & - & $*$ \\
\hline $\begin{array}{l}\text { Post-harvest } \\
\text { protection }\end{array}$ & Biomass & - & $* * *$ & - & - & - & - \\
\hline
\end{tabular}


Table S7: Results of tests for model heterogeneity for non-targeted species $(*<0.05, * *<0.01, * * *<0.001$ or “-” = not significant). Results are only shown if tests for total heterogeneity $(Q t)$ were significant (see Table 1$)$.

\begin{tabular}{cccccccc}
\hline \multirow{2}{*}{ Benefit } & Metric & Compliance & Fishing Pressure Outside & PHC Harvest Effort & Size & Time Closed & Years Established \\
\hline \multirow{2}{*}{ Pre-harvest protection } & Abundance & - & - & Not Relevant & - & - & - \\
& Biomass & - & - & Not Relevant & - & - & - \\
\hline \multirow{2}{*}{ Harvest } & Biomass & - & - & - & $*$ & - & - \\
\hline \multirow{2}{*}{$\begin{array}{c}\text { Post-harvest protection } \\
\end{array}$} & Abundance & - & - & - & - & - & - \\
& Biomass & - & - & $*$ & - & - & - \\
\hline
\end{tabular}




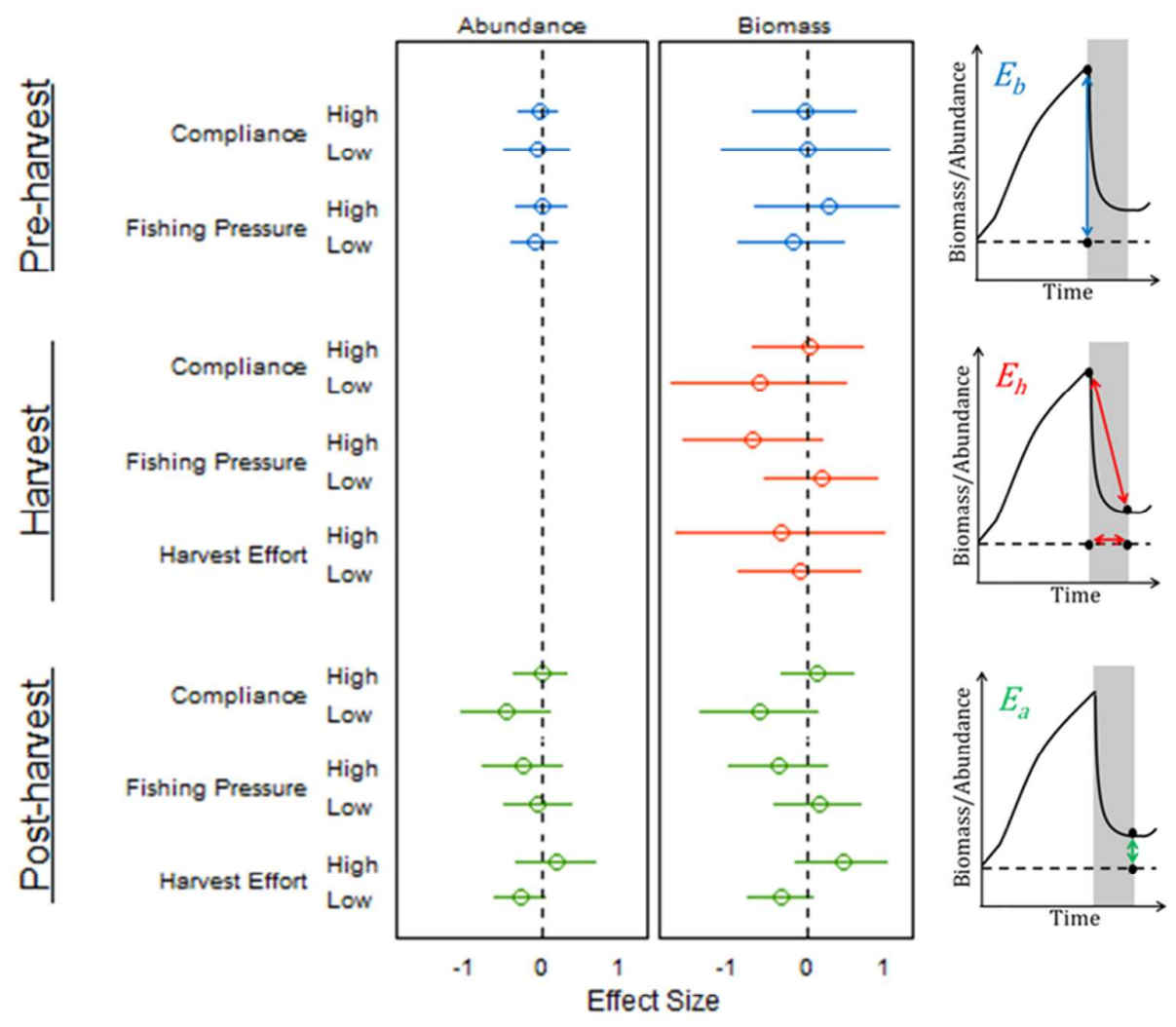

Fig. S1: The influence of categorical co-variates on PHC pre-harvest, harvest and post-harvest benefits for nontargeted species abundance and biomass. Conceptual diagrams showing the effect size calculations are displayed on the left for the pre-harvest $\mathrm{E}_{\mathrm{b}}$ (blue), harvest $\mathrm{E}_{\mathrm{h}}$ (red) and post-harvest $\mathrm{E}_{\mathrm{a}}$ (green). Open circles represent results where the $95 \%$ confidence interval of the effect size does not overlap zero. 